\title{
The Efficiency of Indian Banks: A DEA, Malmquist and SFA Analysis with Bad Output
}

\author{
Ather Hassan Dar ${ }^{1}$. Somesh Kumar Mathur ${ }^{1}$. Sila Mishra ${ }^{1}$
}

Accepted: 19 July 2021 / Published online: 3 September 2021

(c) The Indian Econometric Society 2021

\begin{abstract}
In the recent years, the burgeoning non-performing assets (NPAs) have become a matter of concern and scrutiny in India as the surge in NPAs impinge on the credit services of the banks, make the banks vulnerable to external shocks, leave them with less cushion in case of idiosyncratic shocks and thus, leading to the abrasion of their productive capital. In this backdrop, some very normative questions become inevitable. How has the technical efficiency of the banks in India changed over time especially after the asset quality review, 2016? How does undesirable output like nonperforming assets (NPA) impact the technical efficiency of banks in India? Does technical efficiency have anything to do with the ownership of banks? These are some of the questions we endeavour to answer through our study by employing three cornerstone methodologies namely DEA, Malmquist productivity index and SFA in the banking sector for the period 2014-2020.The results obtained from employing DEA and SFA both points toward the heterogeneity in the technical efficiency of public sector banks and private sectors banks operating in India. The results obtained from DEA are majorly three-fold. Firstly, private sector banks have fared better than the public sector banks, while the SFA scores show that the public sector ownership promotes efficiency. Secondly, the technical efficiency of public sector banks has consistently been falling from 2014 to 2017 only to rise in the later years, evidence corroborated by the SFA scores also. This trend is in line with the slew of measures adopted by the government and RBI like AQR and mergers of banks subsequently. Although according to the Malmquist productivity decomposition results, we find that productivity of banks have been falling for the period 2014-2020. Thirdly, the non-performing assets are detrimental for the efficiency of the banks. Like DEA, the SFA results also shows the presence of technical inefficiency in the Indian banking sector and a similar trend in the technical efficiency wherein the scores decline from 2014 through 2017 and then they rise subsequently.
\end{abstract}

Keywords Bank efficiency · Frontier - Panel data - Bad output - DEA - SFA · Malmquist Index · TOBIT $\cdot$ Time-varying parameter $\cdot$ NPA $\cdot$ India

Extended author information available on the last page of the article 
JEL Classification G21 · G20 - C14 · D24

\section{Introduction}

The progress of the financial sector is deemed as sine qua non of robust economic growth and development. Additionally, banks play a critical role in the financial market hence, any management crisis would be entailed by an unprecedented degree of financial predicament, social cost, and thus has a potential for economic crisis. Banks play a very critical role in the development process of an economy (Tsolas and Charles 2015) given that they channelize the funds to their most productive uses in the economy. McKinsey's Report (2019) has raised concerns over the banks across the world as growth decelerates and has further stressed upon the urgency to consider a 'suite of radical organic or inorganic moves'. Drawing a parallel between the banks in emerging countries and in developed nations, the report has identified waning Return On Tangible Equity (ROTE) from 20\% in 2013 to $14.1 \%$ in 2018 especially, on account of digital disruption in emerging nations in contrast with the developed nations, where the banks have managed to strengthen productivity and have witnessed a surge in ROTE from 6.8 to $8.9 \%$ over the same period. Interestingly, India in this scenario is an interesting case with the World Bank anticipating India's share in global investments to almost double by 2030 and designating the nation as a "Powerhouse in global savings and investment".

With 158,373 functioning offices of commercial banks in India as on March, 2021, there are 14.1 banks and 20.95 ATMs per 1,00,000 adults in India (World Bank, 2019) making the Indian banking system one of the largest in the world. Adapting to the technological shift globally, since 2015, Indian banking sector has taken a quantum leap as the banks transformed their business models from brick-and-mortar to digital modes of transaction. But, for a well-functioning banking sector what matters apart from the deposits is the mechanism through which the savings are allocated as investments or credit. The banking sector in India is characterized by large chunks of non-performing assets which came into limelight post 2016 when the asset quality review (AQR) was conducted. The AQR basically classifies the loans into performing and non-performing. According to the central bank of the country, the RBI, the percentage of the bad loans jumped to as high as $80 \%$ in the financial year 2016 due solely to the AQR. Since bad loans greatly influence the efficiency of the banks, the AQR has shown us how better our banking system is doing and also the need to monitor and evaluate the performance of these banks. The AQR has impacted almost all of the Indian public sector banks while only a few major private sector banks were impacted. Therefore, post AQR the gap between the efficiencies of public and private sectors banks is bound to decrease given the fact that these banks may actively deal with the bad loans in the aftermath of AQR. The burgeoning NPAs have become a matter of concern and scrutiny because it impinges on the credit services of the banks, make them vulnerable to external shocks, leaves them with less cushion in case of idiosyncratic shocks and thus, leading to the abrasion of their productive capital. Ghosh et al. (2016) by developing a baseline regression model have 
provided corroborative evidence on the vulnerability of the banks due to soaring non-performing loans. The vicious cycle demands urgent measures to gauge the bank's financial health, necessitating the adoption of a cocktail-based approach as chalked out by the RBI.

In the recent past, there has been a shift in policy toward the privatization of the publically owned banks. There is thus a need to analyse the relative performance of the nationalized banks as well as the privately owned banks so as to evaluate the recent policy change. The bank is considered as efficient if there is no way it can produce more outputs with the given level of the inputs or vice versa. In the economics jargon such an efficiency concept is called the technical efficiency. Since India has been growing rapidly post the economic liberalization and is currently one of the fastest growing economies, the importance of robust and efficient banking system is evident. An efficient and vibrant banking system in addition to generating huge positive externalities also enhances the overall efficiency of all the financial system in a country. In line with this some normative questions become inevitable. How technically efficient are banks in India? How does undesirable output like non-performing assets (NPA) impact the technical efficiency of banks in India? Does technical efficiency have anything to do with the ownership of banks? And what is the degree of heterogeneity in the banks in India based on the ownership? These are some of the questions we endeavour to answer through our study. The reason stems from the fact that following the slowing domestic and global activity the studies assessing the impact of non-performing loans on profitability and size of the banks have gained traction among scholars. Measurement of the performance of banks has the potential to gauge the relative efficiency and recognize the main factors underpinning the inefficiency. Among other techniques, by using data envelopment analysis (DEA), stochastic frontier approaches (SFA) and financial ratio analysis, performance of the banking sector could be evaluated (Chiu et al. 2016). Emrouznejad and Yang (2018) have presented a survey of the first 40 years of scholarly literature in DEA and have reported that there has been an 'exponential growth' in the number of publications related to theory and applications of Data Envelopment Analysis (DEA).

Economic efficiency of a bank comprises allocative and technical efficiency. Technical efficiency on the one hand measures the potential of a bank to derive maximum output from the limited input; allocative efficiency on the other hand takes into consideration the prices of inputs and gauges the ability of the firm to produce the output optimally. Estimation of these efficiency demands the determination of an unknown production frontier. DEA determines this production frontier non-parametrically and SFA estimates the same parametrically (Coelli et al., 2005). Taking a cue from the literature we strive to corroborate our findings with the help of DEA, Malmquist productivity index and SFA. Furthermore, through two different techniques, parametric and nonparametric, our findings have important implications for the policymakers in improving the performance and technical efficiency of India's banking sector. Our purpose is not to comment on the validity and efficacy of the models but to underscore the inconsistencies in the result obtained from both these methodologies in the current context. We have employed the dataset extracted from RBI for the period 2014-2020. For the analysis we used STATA and the MaxDEA software. 
The rest of this paper proceeds as follows. In "Background" we provide a brief background of the study following which we briefly review the earlier studies concerning the efficiency of banks in India with special emphasis on accounting for NPAs in "Literature Survey". In "Objectives and Contribution of the Current Study" we present the objectives of the current study. Data and methodology in "Data and Methodology" is followed by the results in "Empirical Results". We end the paper with the conclusions and policy implication in "Conclusion and Policy Implications".

\section{Background}

\section{Structure of the Indian Banking System}

The Indian banking industry is centrally governed by the Reserve Bank of India, which is the central bank of the country. Its major functions are to oversee the commercial banks of the country and to carry out the monetary policy besides other huge responsibilities that any central banks has in every country. At a lower level the Indian banking system is characterized by the commercial and cooperative banks, however the commercial banks are the single largest asset holders accounting for about $90 \%$. The Indian commercial banks are then further categorised into scheduled and un-scheduled commercial banks. The scheduled banks are those banks that are included in the second schedule of the Reserve Bank of India Act, 1934. The scheduled commercial banks are further classified into three major categories based on the ownership status: (1) public sector banks, (2) private sector banks and (3) foreign banks. The public sector banks are largely owned by the government of India (more than $50 \%$ of the stake) and are subjected to the regulations of the government. The private sector banks on the other hand are owned privately by the individuals; however, they too are subjected to heavy regulations of the government (Banerjee et al. 2004) (Fig. 1).

\section{Techniques of Measuring Bank Efficiency}

Measuring the efficiency of a bank is not a very straight forward problem. This is due to the fact that not all banks are the same in terms of the environments they are

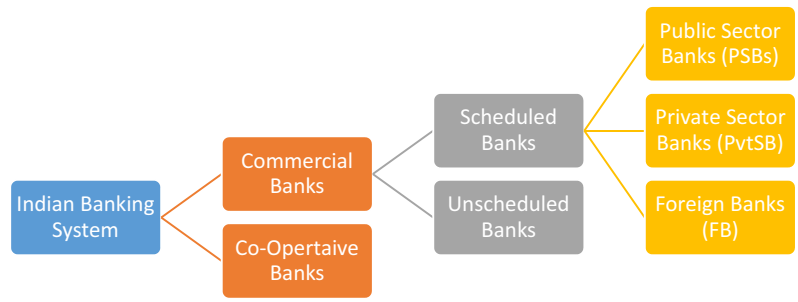

Fig. 1 Structure of Indian Banking System 
operating in, the size of the banks and the services they provide to their customers. There are however numerous techniques that are helpful in measuring the efficiency of the banks. They range from the traditional ratio analysis to the regression based parametric methods to the new non parametric frontier based methods. While the ratio analyses are the simplest methods to analyse the efficiency scores of the banks they have various inherent limitations that make them less valuable in presence of more advanced parametric and non-parametric techniques. The most widely used regression based parametric technique is the stochastic frontier analysis (SFA) while data envelopment analysis (DEA) is the widely used non-parametric technique. The major differences between these two competing methods are the assumptions that are imposed on the specification of the frontier, the existence of a random error and the distribution of the inefficiencies and the random error (Berger and Humphery 1997). While SFA is a regression based approach and assumes an underlying functional form (Cobb Douglas, Translog, etc.) the DEA on the other hand is a non-parametric technique and does not assume any particular underlying functional form. The advantage of using non-parametric DEA technique over the deterministic SFA techniques is that the DEA is more flexible in the sense that it allows use of multiple input and output vectors while calculating the efficiency scores of the decision making units unlike SFA where we can use only a single output and single or multiple input variables. In addition, DEA also allows for accounting the undesirable outputs (inputs) which cannot be accounted for in the SFA methods.

\section{Literature Survey}

The concept of economic efficiency indicates the best attainable operation of a commodity or service. Thus, it is a sum and outcome of static and dynamic efficiency (Petrou 2014; Cabral 2000; Church and Ware 2000; Holmstrom and Tirole 1989; Schmalensee 1989). While the static efficiency operates under allocative and productive efficiency, dynamic efficiency occurs with the introduction of new products and improvisation of the existing production techniques in the market (Petrou 2014). In a nutshell, economic efficiency stems from the process of curtailing waste and augmenting the efficiency. The application of static efficiency, especially the productive efficiency has gained traction among researchers in the recent past. The literature suggests two main approaches for determining the technical efficiency of banks: parametric techniques, like stochastic frontier analysis (SFA), and non-parametric techniques, like data envelopment analysis (DEA) (Bayeh et al. 2018). Stochastic frontier analysis (SFA) was proposed by Aigner et al. (1977) and Meeusen and Van den Broeck (1977) independently which involves an econometric method (Coelli et al. 2005). Data envelopment analysis (DEA) on the other hand was first used in Charnes and Cooper (1984). It involves mathematical programming methods to construct a frontier by using the data. The efficient frontier of the production set is typically represented by the technically efficient combinations of input and output. This frontier depicts the maximal outputs that can be produced for some given underlying inputs (Bogetoft 2012). A standard DEA follows some assumptions likefree disposability (producing less with more), returns to scale; convexity (averages 
are preferred over extreme); additivity and replicability (Bogetoft and Otto 2010). Thus, DEA assumes weak disposability according to which there is no possibility for the reduction of undesired outputs freely. Furthermore, this safe assumption has less power. "In other words, desirable and undesirable outputs are null joint which means that good output production inevitably involves bad output generation" (Shirazi and Mohammadi 2019). Contrary to this safe assumption of weak disposability which has less power, is the strong disposability (Scheel 2001). However, in reality, decision making units experience some undesirable outputs that are ought to be curtailed. Fare et al. (1989) was the first paper to treat the matter of desirable and undesirable outputs asymmetrically wherein the authors had developed a directional-vector approach in output-orientation (Tone 2004).

To buttress the research on an alternative methodology, Scheel (2001) in their study has classified the approaches to incorporate undesirable output into direct and indirect approaches. In order to treat the undesirable output, in the direct approach, original output data is employed on which further modifications of the assumptions pertaining to the structure of technology are made. On the other hand, in the indirect approach the values of the undesirable outputs are transformed into monotonically decreasing functions which are further included as desirable output in the technology set. The underlying rationale behind transforming the undesirable output is the analogy that the values of the transformed function are indirectly proportional to the undesirable output (Scheel 2001). Indirect method has been a popular method among researchers (Cherchye et al. 2015). However, the method is also subject to certain limitations which have been clearly pointed out by Cecchini et al. (2018). Firstly, the indirect method doesn't incorporate the reduction in input and increment in output simultaneously i.e. the models are either output-oriented or input-oriented and does not allow us to estimate input and output slacks concomitantly. Secondly, the results of indirect approach are highly sensitive to the type of transformation being made. Taking a cue from the limitation stated above a non-radial parametric approach proposed by Chung et al. (1997) is employed by researchers. A nonradial parametric method allows for the expansion of output along with reduction of inputs. Unlike the indirect method, the model illustrated in Chung et al. (1997) makes use of directional distance function as a component in the new productivity index modeling the production of both good and bad output. Barros et al. (2012) have categorized the literature on the non-radial models into three groups-Russell measure (Fare and Lovell) with an input-oriented form, Additive model (Charnes et al.) and Slacks-based model (Tone 2004).

Among the non-radial and non-oriented measures, Slack-Based Measure has gained popularity among the researchers. This model does away with the assumption of proportionate changes in inputs and outputs, and has directly dealt with slacks (Tone 2011). Furthermore, it has been designed to meet three conditionsunit invariance (measure is unwavering in the unit of data), monotone (monotone decreasing in each slack in inputs and output) and translation invariance (invariant under the parallel translation of coordinate systems (Tone 2001). Additionally, in Tone (2001) the author has put-forward a slack-based measure with data envelopment analysis which has been further extended in Tone (2004) to handle the nonseparable desirable and undesirable output (SBM-NS output model) (Table 1). 
Table 1 Categorization of DEA models based on the findings of Tone (2004)

\begin{tabular}{lll}
\hline & Radial & Non-radial \\
\hline $\begin{array}{l}\text { Oriented } \\
\text { Non-oriented }\end{array}$ & Radial and oriented & Non-radial and oriented \\
& Radial and non-oriented & $\begin{array}{c}\text { Non-radial and non-oriented } \\
\text { (captures all the aspect of } \\
\text { efficiency) }\end{array}$ \\
\hline
\end{tabular}

Radial model: a model wherein proportional increase or decrease of outputs/inputs is the primary concern in the measurement of efficiency. This model does not take into account slacks. Oriented model: input and output oriented model. In the input oriented model, output is inconsiderable and in the outputoriented model, input is held trivial

Halkos and Petrou (2019) have provided a critical review of four possible ways followed in the literature to treat undesirable output in data envelopment analysis. These methods are prima facie ignoring the undesirable output from the production function, treating them as regular inputs, treating the undesirable output as normal outputs and performing necessary transformations to take the undesirable output into account. Yang and Pollitt (2007) have also proposed a model wherein they have incorporated weak and strong disposability features among various undesirable outputs based on the technical nature of the undesirable outputs.

In pursuit of establishing a pragmatic model where the production process also generates undesirable output, several attempts have been made in the past. The efficiency of banks is a matter of deep concern among bank managers and regulators (Bayeh et al. 2018). Given the uncertainty, an efficient bank supports credit growth, and provides the best possible products and services at the lowest cost. Accordingly, any proposed strategic policy and bank regulation should consider potential bank outputs in relation to invested inputs (Bayeh et al. 2018). Literature provides enough evidence that the development of the banking sector positively predicts growth, capital accumulation, and productivity improvements (Levine and Zervos 1998a, b ).

The literature suggests primarily two main approaches used for measuring bank efficiency: parametric techniques (stochastic frontier analysis-SFA), and non-parametric techniques (data envelopment analysis-DEA) (Bayeh et al. 2018). Some selected studies employing DEA and SFA are Berg et al. 1993; Bhattacharyya et al. 1997; Charles and Kumar 2012; Chatterjee 1997; Fall et al. 2018; Favero and Papi 1995; Goyal et al. 2019; Kohers et al. 2000; Kumar et al. 2010, 2016; Kumbhakar and Sarkar 2003; Mester 1996; Miller and Noulas 1996; Mohan and Ray 2004; Rangrajan and Mempilly 1972; Resti 1997; Saha and Ravisankar 2000; Sahoo et al. 2007; Sathye 2003; Silva et al. 2017; Stewart et al. 2016; Subrahmanyam 1993; Thoraneenitiyan and Avkiran 2009; Thyagarajan 1975; Wanke et al. 2020; Wheelock and Wilson 1995; Yue 1992) among others.

A plethora of researchers in the past have attempted to evaluate the efficiency of Indian commercial banks using the data envelopment analysis (DEA). The average efficiency scores of the Indian banks are comparable with the mean efficiency score of the banks in other parts of the world (Sathye 2003) despite the fact that the banks in India face surmounting non-performing assets compared to the other emerging economies like China, Mexico and Brazil (Hafsal et al. 2020). While most 
of the earlier studies have conclude that the public sector banks have performed better than private sector banks (Bhattacharyya et al. 1997; Sathye 2003; Sengupta and De 2020; Ray and Das 2010; etc.) recently various studies have found the private sector banks outperforming the nationalized banks (Tzeremes 2015; Mukta 2016). In the recent times post the asset quality review (AQR) 2016, the Indian commercial banks have been facing the problem of huge non-performing assets (Hafsal et al. 2020). According to the financial survey report 2017, the bad loans problem has been a serious issue facing the public sector banks than the private banks. The gross NPA of public sector banks was $14.6 \%$ of the total loans while it was $11.2 \%$ for the other banks. The higher bad loans of the public sector banks have greatly impacted them adversely. Rajaraman and Vasishtha (2002) show that the public sector banks which have relatively higher NPAs also have less efficiency. While existing literature show that reducing the non-performing assets as well as optimizing on staff and bank branches will have efficiency gains (Sathye 2003) we would like explore ways in which we can take the undesirable non-performing assets into account while calculating the efficiency scores of the Indian banks.

Majorly, there are four methods in which bad outputs can be accounted for in the DEA methodology; ignoring the undesirable outputs, treating undesirable outputs as inputs, treating the undesirable outputs in the non-linear models and applying the necessary transformations:

a) Ignoring the undesirable outputs The easiest way in which bad outputs can be treated in the DEA is to simply ignore it altogether from the production process. However, this might not be the best way to deal with the undesirables since it simply assumes that bad outputs have no role in the evaluation process of the decision making units hence this will give the misleading outcomes (Yang and Pollitt 2009). In many cases, undesirable outputs are usually the by-products such that they cannot be separated from the desirable outputs. Therefore, ignoring these bad outputs might not be a feasible strategy. Hailu and Veeman (2001), Pathomsiri et al. (2008), Yang and Pollitt (2009) adopt this strategy to deal with bad outputs.

b) Treating undesirable outputs as inputs Another simple yet more convenient way to deal with bad outputs is treat them as inputs. The basic rationale behind this approach of accounting for undesirable output is that both the normal inputs as well as the undesirable outputs should be decreased. Researchers who used this simple and innovative method include Reinhard et al. (2000), Hailu and Veeman (2001), De Koeijer et al. (2002), Lansink and Bezlepkin (2003). In particular Fukuyama and Weber (2008) used this approach to model the undesirable nonperforming assets in the loan production process of the Japanese banks.

c) Treating the undesirable outputs in the non-linear models This procedure includes the use directional distance function to evaluate the efficiency of the decision making units when there are both the desirable as well as the undesirable outputs involved in the production process. However, in this approach as well the desirable outputs are maximized while the undesirable outputs as well as the inputs are minimized directionally.

d) Applying the necessary transformations Under this approach researcher apply some monotonic transformations such that the desirable outputs are maximized 
while undesirable outputs are minimized at the same time. One such transformation is to simply treat the undesirable outputs as negative of it such that it now becomes desirable.

In this paper we adopt the second approach to account for undesirable non-performing assets in the DEA methodology. Guo and $\mathrm{Wu}$ (2013) while differentiating between the desirable and undesirable outputs extended the traditional data envelopment analysis model to rank the decision making units, accounting for the undesirables in arriving at the efficiency scores. They treat the undesirable outputs in their model as inputs based on the fact that these bad outputs incur costs to the decision making units and they want to reduce them while trying to hold the current level of output constant. In our study we adopt Guo and Wu (2013) extended model where we include Net NPAs as input in our models to calculate the efficiency scores of Indian public and private sector banks. Table 2 below presents the review of few select studies that have incorporated the undesirable outputs in their models.

\section{Objectives and Contribution of the Current Study}

The present study delves into developing a different framework to compare the banks in India which are here viewed as production units in the realm of rising NPAs. The objectives of the present study discern itself from the proliferating stream of literature construing the technical efficiency of banks in India and abroad. In the current study we intend to work in the following directions. Firstly, we would work out the technical efficiency of commercial banks in India through DEA and SFA. Secondly, we would strive to ascertain the change in productivity in the Indian banking sector over 2014-2020 and disentangle the change in productivity due to catching up phenomenon and shifting of the production frontier. Thirdly, in order to explain the variability in the efficiency score we would perform Tobit analysis in a panel framework.

On the basis of the results obtained from TOBIT we would further comment on the appropriateness of the models. Fourthly, to give a framework/model for analyzing bad outputs in the DEA and the SFA framework. Fifthly, we would carry out a comparative analysis of the technical efficiency scores obtained from DEA and SFA across private and public sector banks over time. Sixthly, given the panel data set of 2014-2020 we would endeavour to advocate policy framework for ameliorating the efficiency and productivity of the Indian banking system during and post COVID.

\section{Data and Methodology}

\section{Data}

\section{Input-Output Selection}

There are two major approaches to the input and output selection in the data envelopment analysis. Benston (1965) developed the Production Approach, which 


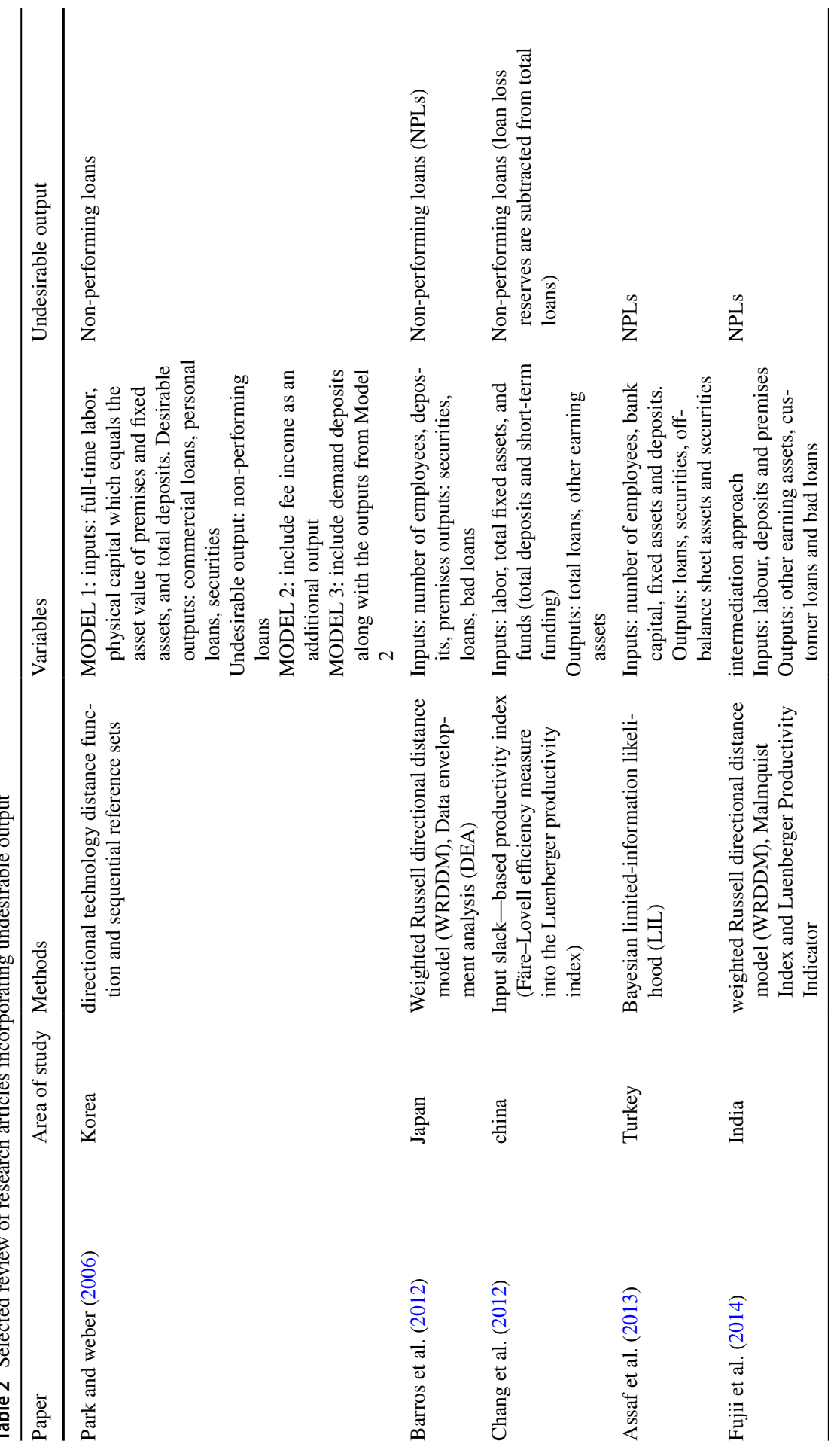




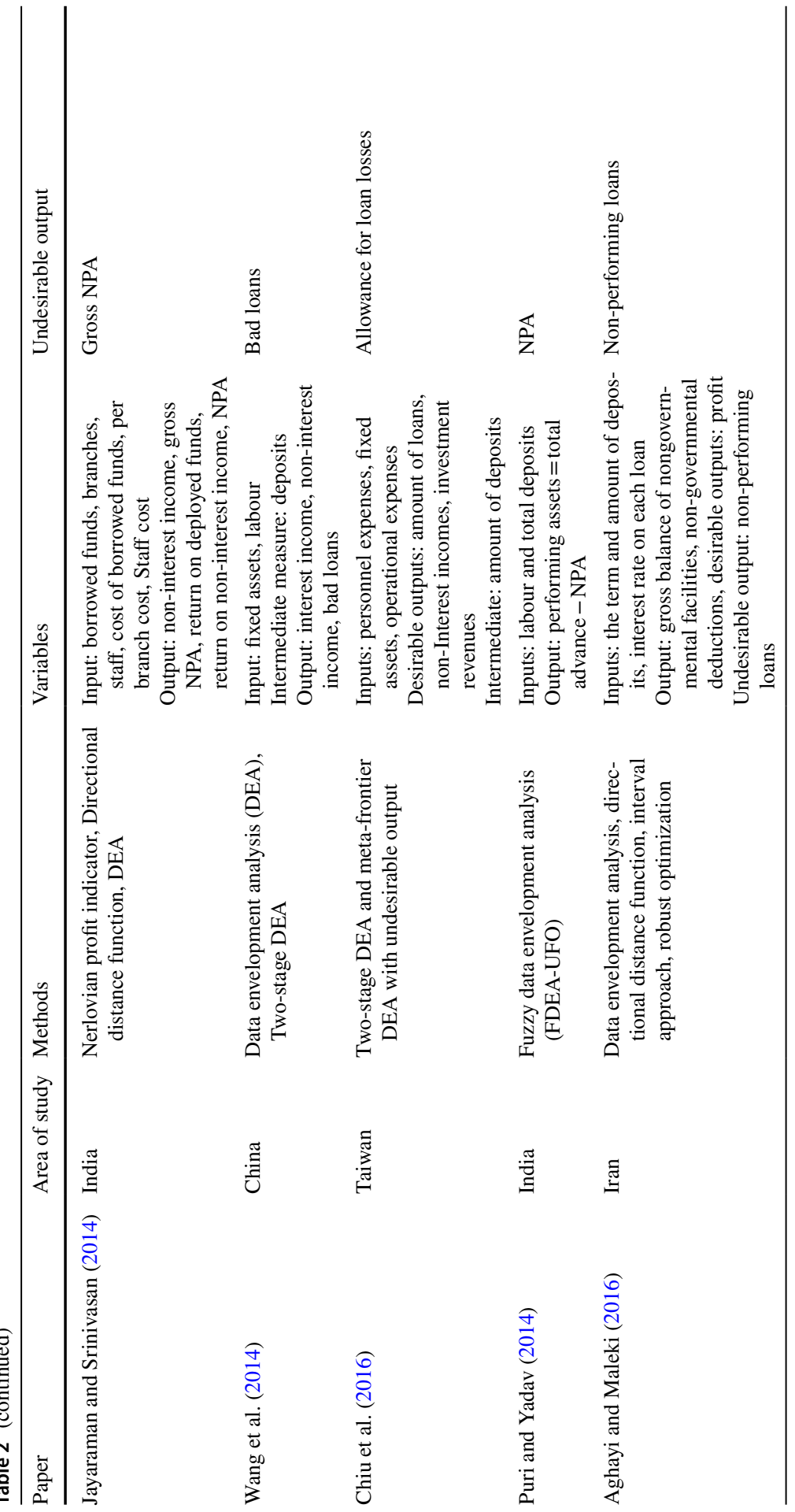




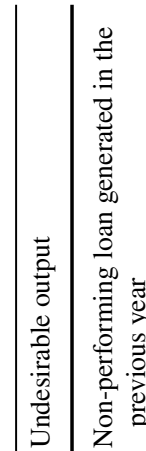

艺艺

艺

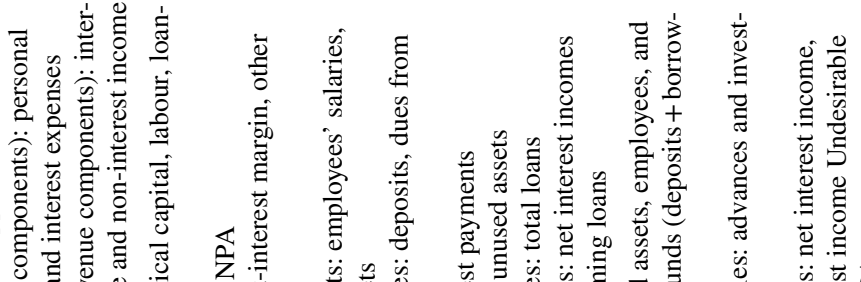

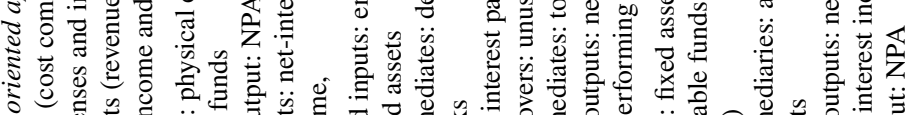

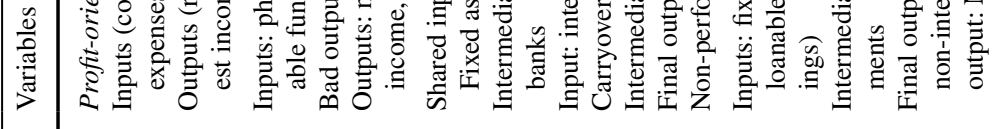

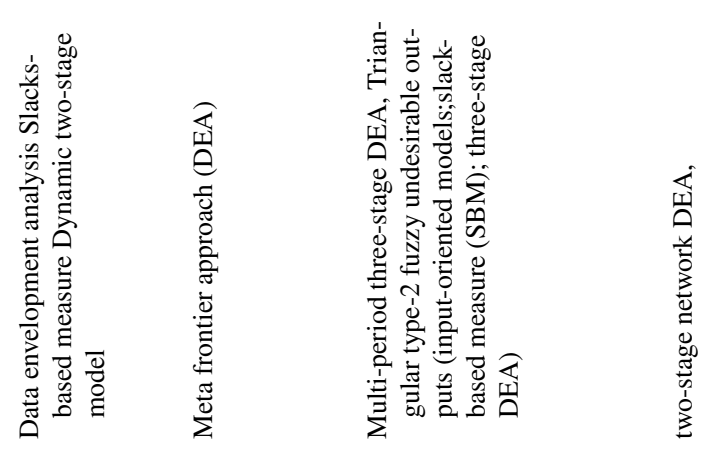

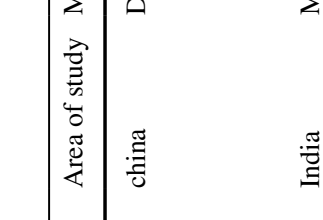

急急

$\stackrel{g}{g}$

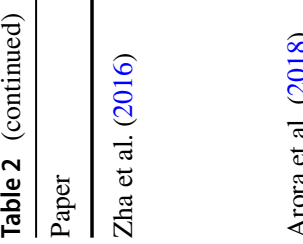

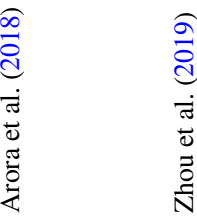

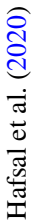




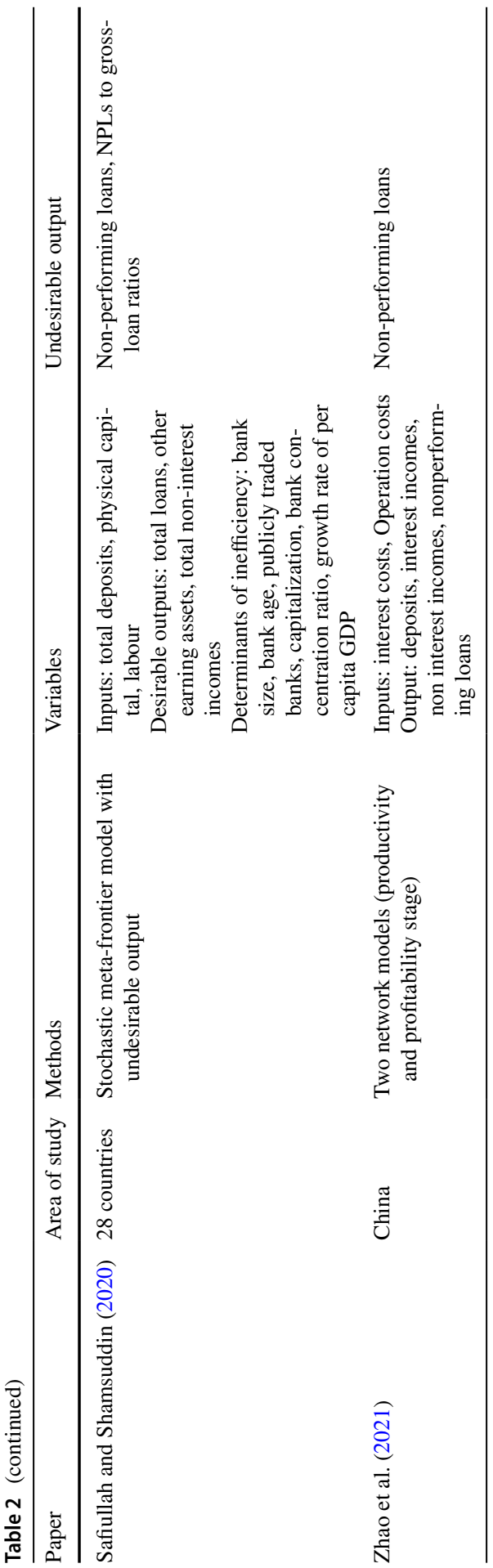


views banks primarily as the service providers. The inputs are mainly the labour, capital and other physical assets, while the outputs generally are the loans and deposits. Sealey and Lindley (1977) developed the Intermediation Approach which considers a bank as an intermediary between the lenders and borrowers. The main function of the bank, according to this approach, is thus to make funds available using its inputs. The major inputs under this approach include labour, capital, assets etc. while outputs include loans, investments among other variables. According to Berger and Humphrey (1997), intermediation approach is the more appropriate for evaluating the bank efficiency at an aggregated level while production approach is more suited at the branch level. Arrif and Luc (2008) have used total deposits, number of employees and fixed assets as inputs and investments and total loans as outputs in their study. Luo (2003) also use number of employees, total assets and shareholders' equity as inputs and profits and revenue as outputs. In the Indian context, Kumar and Gulati (2010) have used advances and investment as output variables and physical capital (value of fixed assets), labour (number of employees) and loanable funds (deposits and borrowings) as inputs. In this study we follow Das et al. (2005), Kumar and Gulati (2010) and Mukta (2016) we use three output variables investment, loans, non-interest income and four input variables borrowings, labour, fixed assets and equity. In addition, the extended version of the DEA model incorporates NPA, a bad output, (Mukta 2016) as an input variable in the model to compute the technical and scale efficiency scores.

\section{Variables and Data Sources}

Table 3 describes all the variables that we use in this study. The data for the study has been extracted from the Statistical Tables relating to Banks in India, issued by the Reserve Bank of India. The time period of the study is 2014-2020. We choose this time period because there have been numerous studies that have worked with the previous data, however our purpose is in this paper is to analyse the efficiency score in the recent period so as to evaluate the recent policy shift toward privatization/ mergers of the nationalized banks. Appendix Table 13 gives the summary statistics of the various input and output variables over the time period 2014-20. On an average the public sector banks have higher amount of investments, advances, non-interest incomes, borrowings, fixed assets, labour expenses and equity. In line with this from the descriptive statistics presented in Appendix Table 13 we could observe a high degree of variation in the NPAs of the public sector banks over the private sector banks. 


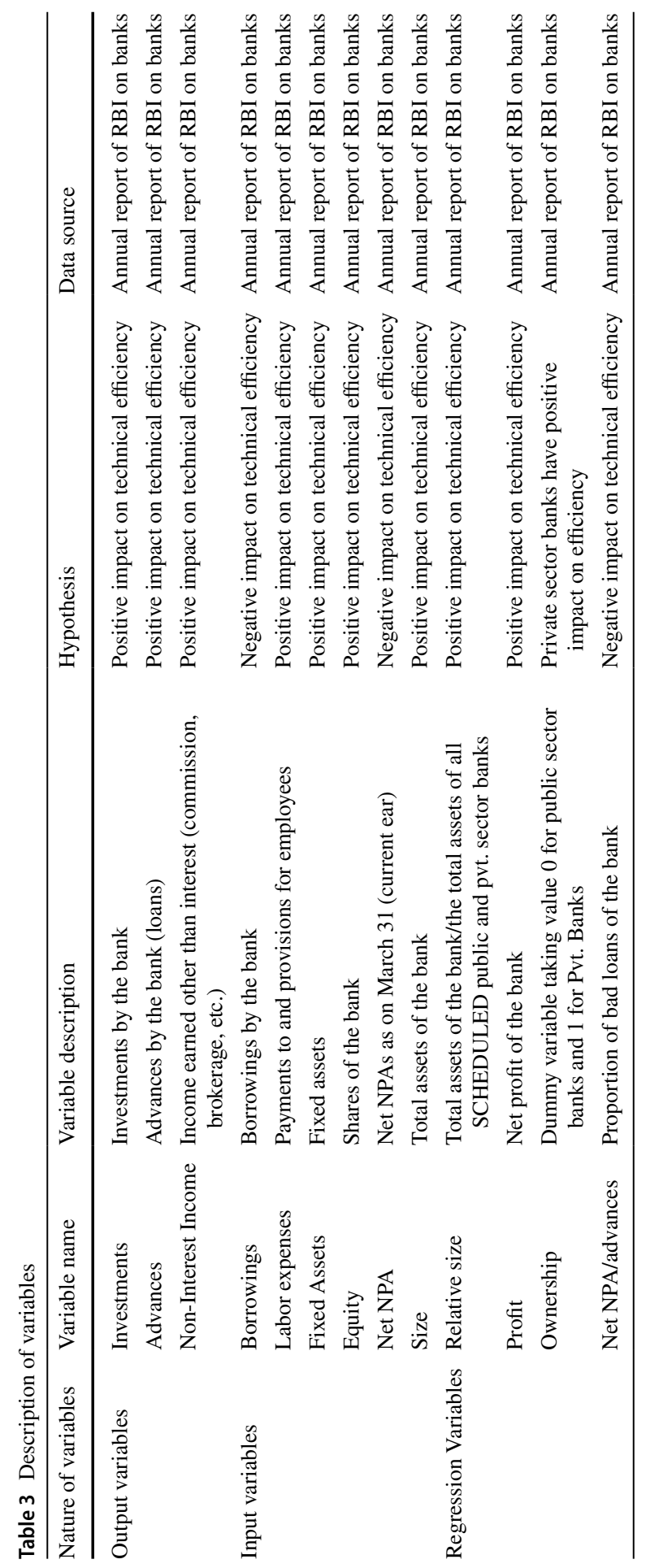




\section{Methods}

\section{Data Envelopment Analysis (DEA)}

In this study we use both the CCR (1978) and the BCC (1984) models to evaluate the efficiency scores of the Indian public and private sector banks. Following Guo and $\mathrm{Wu}$ (2013) we augment the models such that the undesirable outputs enter the constraints. That is, let there be $N$ decision making units, each $\mathrm{DMU}_{\mathrm{n}}$ $(\mathrm{n}=1,2, \ldots, \mathrm{N})$ employs $m$ inputs to produce $s$ desirable outputs and $k$ undesirable outputs. The inputs, desirable outputs and undesirable outputs of $\mathrm{DMU}_{\mathrm{n}}$ are respectively given by $x \_i n(\mathrm{i}=1, \ldots, \mathrm{m}), y \_r n(\mathrm{r}=1, \ldots, \mathrm{s}), b \_t n(\mathrm{t}=1, \ldots, \mathrm{k})$. Assuming strong disposability and that the inputs and bad outputs can be reduced proportionately while holding desirable output constant, we can find the relative efficiency of $\mathrm{DMU}_{\mathrm{n}}$ as follows.

\section{Input Oriented CCR Model Incorporating Undesirable Outputs}

$\min \theta_{p}$

Subject to

$$
\begin{gathered}
\sum_{n=1}^{N} \lambda_{n} x_{i n} \leq \theta_{p} x_{i p}, i=1,2, \ldots, m ; \\
\sum_{n=1}^{N} \lambda_{n} y_{r n} \geq y_{r p}, r=1,2, \ldots, s ; \\
\sum_{n=1}^{N} \lambda_{n} b_{t n} \geq \theta_{p} b_{t p}, t=1,2, \ldots, k ;
\end{gathered}
$$

$\lambda_{n} \geq 0, n=1,2, \ldots, N$ for Constant Returns to Scale technology.

Imposing the restriction, $\sum \lambda_{n}=1$ we get the input oriented BCC Variable Returns to Scale model. The dual of above input oriented CCR model is given by the following output oriented CCR Model.

\section{Output Oriented CCR Model Incorporating Undesirable Outputs}

$$
\operatorname{Max} \sum_{r=1}^{s} u_{r} y_{r p}
$$

Subject to

$$
\sum_{r=1}^{s} u_{r} y_{r n}-\sum_{i=1}^{m} v_{i n}-\sum_{t=1}^{k} \omega_{t} b_{t n} \leq 0, \forall_{n}
$$




$$
\begin{aligned}
& \sum_{i=1}^{m} v_{i} x_{i p}+\omega_{t} b_{t p}=1, \\
& u_{r}, v_{i}, \omega_{t} \geq 0, \forall_{r} \forall_{i}, \forall_{t}
\end{aligned}
$$

Scale Efficiency Scale efficiency is simply given by the ratio of TE with CRS technology and TE with VRS technology. Thus

$$
S E=\frac{T E^{C R S}}{T E^{V R S}}
$$

\section{Productivity Change: Malmquist Productivity Index}

The Malmquist productivity index measures the productivity change over the years and subsequently decomposes this TFP change into the technological change and the efficiency change. The Malmquist productivity index requires a panel dataset to measure the TFP growth.

The output oriented Malmquist productivity growth index as given by Fare et al. (1994) is given by

$$
m_{o}\left(y_{t+1}, x_{t+1}, y_{t}, x_{t}\right)=\left[\frac{d_{o}^{t}\left(x_{t+1}, y_{t+1}\right)}{d_{o}^{t}\left(x_{t}, y_{t}\right)} \times \frac{d_{o}^{t+1}\left(x_{t+1}, y_{t+1}\right)}{d_{o}^{t+1}\left(x_{t}, y_{t}\right)}\right]^{1 / 2}
$$

This index represents the productivity growth from point $\left(y_{t}, x_{t}\right)$ to point $\left(y_{t+1} \cdot x_{t+1}\right)$. The index is a geometric mean of two output based Malmquist productivity indices where one index uses the period $t$ technology and the other uses the period $t+1$ technology. The value greater than 1 for the index represents a positive TFP growth and a value less than 1 represents a negative TFP growth.

\section{Second Stage Regression Analysis: Tobit Model}

After getting the efficiency scores from the first part of the study we next run a Tobit regression in the pooled framework as well as a Tobit regression in the panel setting to look for the sources of this efficiency, regressing the various technical efficiency scores on the explanatory variables like relative size, profits, Net NPA as a proportion of total advances, and ownership of the bank. Formally,

$$
T E_{b}=\beta_{0}+\beta_{1} \text { relativesize }_{b}+\beta_{2} \text { profit }_{b}+\beta_{3}(\text { NetNPA/Advances })_{b}+\beta_{4} \text { ownership }_{b}+\varepsilon_{b}
$$

where relative size refers to the total assets of the bank as a proportion of assets of all scheduled commercial banks, profit is the net profit of the bank. Net NPA/ Advances refers to the net NPAs of the bank as a proportion of total advances. Ownership is the dummy variable taking value 1 if the bank is a private sector bank and zero otherwise. We also run a random effects Tobit model 


$$
\begin{aligned}
T E_{b t}=\beta_{0} & +\beta_{1} \text { relativesize }_{b t}+\beta_{2} \text { profit }_{b t}+\beta_{3}(\text { NetNPA/Advances })_{b t} \\
& +\beta_{4} \text { ownership }_{b t}+v_{b t}-u_{b t}
\end{aligned}
$$

Ahmad et al. (2015) finds that the size is not a significant factor explaining the efficiency scores of the banks. Taking the total assets as the proxy for size of the bank, Kumar and Gulati (2010) find that smaller banks perform better than the larger banks. Along the similar lines, Ariff and Luc (2008) also find that large sized banks perform less efficiently than the smaller banks. Goswami et al. (2019) also find that bank size is not a significant factor. Thus existing literature suggests that the sign of the coefficient of size is expected to be negative and insignificant. Sharma et al. (2012) finds a positive and significant relationship between profits of a bank and the efficiency. We therefore expect out estimate of coefficient on profit to be positive and significant. Similarly, Ahmad et al. (2015) and Sharma et al. (2012) find a positive and significant relationship between public ownership and technical efficiency of banks. Das and Ghosh (2006) show using a Tobit regression that the banks with fewer non-performing assets are more efficient than those with very high NPAs. They also find public ownership of banks as a positive and significant factor explaining the efficiency.

\section{Stochastic Frontier Analysis (SFA)}

Among the two main approaches of frontier models, other than the most used parametric, linear programming technique named DEA with free disposal hull, there is a parametric model called stochastic frontier analysis (SFA). SFA assumes that most decision making units/firms are either very close to the frontier or are on the frontier. Furthermore, the inefficiency (DMUs away from the frontier) component in SFA can assume any form of distribution- half-normal, truncated normal or exponential. SFA is called parametric because the methodology requires the specification of functional form and establishing distributional assumptions on the inefficiency and noise term, but has the merit that it naturally handles noise in the data (Strange et al. 2021; Kumbhakar and Lovell 2003; Bogetoft and Otto 2011). Similar to the DEA model, the SFA model could be applied in a panel setting. The results obtained from DEA and SFA in most of the studies present contrasting inefficiency and moderately different rankings (Humphrey 2019). The stochastic frontier approach, independently proposed by Aigner et al. (1977) and Meeusen and van den Broeck (1977) specify a composed error with two components: a one-sided error (for non-negative inefficiency effects) and random component. Battese and Coelli (1995) have assumed that inefficiency effects are a function of some factors specific to DMU. We have chosen SFA to complement DEA because we aim at exploring the elasticities of the factors that explain the production and inefficiencies in banks.

In SFA, functional form plays an important role in the estimation of efficiency. There are four kinds of functional form; constant elasticity of substitution (especially, Cobb-Douglas), linear, quadratic, and the translog specification (Baumol et al. 1983). The linear functional form is the simplest but cannot evaluate interactions between factors. The quadratic functional form is well defined for zero values but is rarely employed in efficiency analysis. The Cobb-Douglas functional form 
is widely used and requires further assumptions on the elasticities of substitution in contrast with the translog function which provides a second-order differential approximation and the results provide heuristic explanation. Under the SFA, three different types of efficient frontiers are used to estimate managerial performance comprising cost, revenue, and profit frontiers (Kohers et al. 2000).

$$
y_{i t}=f\left(x_{i t}, \beta\right) e^{U_{i t}}, U_{i t}=u_{i t}-v_{i t} \text { where } \mathrm{i}=1,2 \ldots \ldots, \mathrm{n}
$$

$\mathrm{y}_{\mathrm{it}}=$ output of bank $\mathrm{i}$ in time $\mathrm{t}, \quad \mathrm{x}_{\mathrm{it}}=\operatorname{vector}(1 \times \mathrm{K})$ of input used by bank $\mathrm{i}$ in period $\mathrm{t}$, $\beta=$ vector $(\mathrm{K} \times 1)$ of unknown parameters to be estimated, $\mathrm{u}_{\mathrm{it}}=$ systematic random error, $\mathrm{v}_{\mathrm{it}}=$ non - negative random error component and technical inefficiency effects.

$$
u_{i t} \sim \text { i.i.d }\left(0, \sigma_{u}^{2}\right), v_{i t} \sim \text { i.i.d., } N\left(\mu, \sigma_{v}^{2}\right) \operatorname{cov}\left[x, u_{i t}\right]=0, \operatorname{cov}\left[x, v_{i t}\right]=0, \operatorname{cov}\left[u_{i t}, v_{i t}\right]=0
$$

$\mathrm{u}_{\mathrm{it}}$ subsumes measurement error and other exogenous factors beyond the control of banks).

A major advantage of panel data in SFA is that we can investigate the changes in technical efficiencies over time which is not possible in cross-section data. Based on the technical inefficiency effects there are two structures which are often considered namely time-invariant inefficiency model and the time-varying inefficiency effects model. In the time- invariant inefficiency model the inefficiency effects could be written as:

$$
u_{i t}=u_{i}, i=1, \ldots . . I ; \quad t=1, \ldots . T
$$

Here, the model would either be fixed effects or random effects. Fixed effect model could be determined from standard regression and the random effects model by either OLS or MLE.

On the other hand, in the time-varying inefficiency model we assume that the technical efficiency changes over time (Coelli et al. 2005).

$$
u_{i t}=f(t) \cdot u_{i}
$$

Here, if we look at the $f($.$) this may take either of the two forms:$

$$
\text { Kumbhakar (1990) : } \mathrm{f}(\mathrm{t})=\left[1=\exp \left(\alpha \mathrm{t}+\beta \mathrm{t}^{2}\right)\right]^{-1}
$$

Or

$$
\text { Battese and Coelli (1992) : } \mathrm{f}(\mathrm{t})=\exp [\eta(\mathrm{t}-\mathrm{T}]]
$$

Both these models propose the estimation of parameters using the method of MLE through which we can separate the inefficiency and technological change (Coelli et al. 2005). It is worth mentioning at this juncture that we have employed a production function approach with time-varying technical efficiency model. Additionally, we have assumed the inefficiency term (U_it) to be following truncated normal distribution, whereas, the random error component follows normal distribution which has been followed in Coelli and Battese (1996). The underlying reason given by Coelli and Battese (1996) is that it suffers from much fewer 
computational problems than other distributions (Odeck and Schoyen 2020). The variance parameter is:

$$
\begin{gathered}
\sigma_{U}^{2}=\sigma_{u}^{2}+\sigma_{v}^{2} \\
\lambda=\frac{\sigma_{u}^{2}}{\sigma_{v}^{2}}
\end{gathered}
$$

$\gamma=\frac{\sigma_{u}^{2}}{\sigma_{u}^{2}+\sigma_{v}^{2}} \quad$ where $\quad 0 \leq \gamma \leq 1$

The technical efficiency of banks is given by;

$$
T E_{i t}=\frac{f\left(x_{i t} ; \beta\right) e^{U_{i t}}}{f\left(x_{i t} ; \beta\right) e^{u_{i t}}}=e^{-v_{i t}} \quad \text { where } \quad 0 \leq T E \leq 1
$$

Now, if we consider some other exogenous factors influencing technical inefficiency component $\left(Z \_i t\right)$, then this effect would be subsumed in the $v \_i t$. This model was formulated by Battese and Coelli (1995);

$$
v_{i t}=Z_{i t} \delta+W_{i t}
$$

Taking a cue from the literature we have adopted a trans-log form, because of its flexible functional form (Silva et al. 2017). In the current context we have considered three outputs namely, investments, advances and non-interest income in three different set-ups. Additionally, three explanatory variables-capital strength, labor expenses and borrowings have also been considered. As stated earlier in the research objective we intend to gauge the impact of undesirable output especially, NPAs. So, to contextualize the influence of environmental factors beyond the control of banks, variables like size, ownership and NPAs have been incorporated in the model. Table 4 presents the hypotheses that we test in the SFA analysis.

\section{Empirical Results}

\section{Data Envelopment Analysis (DEA)}

The appendix Table 14 reports various DEA efficiency scores that were calculated using the MaxDEA software. Table 5 below summarizes the DEA efficiency

Table 4 Hypotheses tested in SFA

\begin{tabular}{ll}
\hline Hypothesis & Meaning \\
\hline$H_{0}: \gamma=0$ & $\begin{array}{l}\text { Technical inefficiency effects are not random. It is tested by using LR-test } \\
L R=-2\left\{\ln \left[L\left(H_{0}\right)\right]-\ln \left[L\left(H_{1}\right)\right]\right\}\end{array}$ \\
$H_{0}: \delta=0$ & $\begin{array}{l}\text { Technical inefficiency effects are not influenced by the level of the explan- } \\
\text { atory variable }\end{array}$ \\
Kruskal Wallis test & Difference among the k populations(equality of the population rank) \\
\hline
\end{tabular}


Table 5 Summary statistics of DEA efficiency scores

\begin{tabular}{lcccccccccc}
\hline Variables & $\mathrm{N}$ & Mean & SD & Min & Max & P25 & P50 & P75 & P90 & P99 \\
\hline Ownership: Public Sector Banks & & & & & & & \\
CRSTE & 167 & 0.836 & 0.138 & 0.520 & 1 & 0.713 & 0.857 & 0.979 & 1 & 1 \\
OVRSTE & 167 & 0.950 & 0.080 & 0.676 & 1 & 0.913 & 1 & 1 & 1 & 1 \\
OSE & 167 & 0.879 & 0.113 & 0.576 & 1 & 0.801 & 0.900 & 0.999 & 1 & 1 \\
IVRSTE & 167 & 0.939 & 0.100 & 0.578 & 1 & 0.894 & 1 & 1 & 1 & 1 \\
ISE & 167 & 0.891 & 0.110 & 0.580 & 1 & 0.816 & 0.916 & 1.000 & 1 & 1 \\
Ownership: Private Sector Banks & & & & & & & \\
CRSTE & 147 & 0.912 & 0.125 & 0.537 & 1 & 0.834 & 1 & 1 & 1 & 1 \\
OVRSTE & 147 & 0.949 & 0.089 & 0.606 & 1 & 0.914 & 1 & 1 & 1 & 1 \\
OSE & 147 & 0.960 & 0.080 & 0.554 & 1 & 0.954 & 1 & 1 & 1 & 1 \\
IVRSTE & 147 & 0.946 & 0.093 & 0.604 & 1 & 0.915 & 1 & 1 & 1 & 1 \\
ISE & 147 & 0.963 & 0.075 & 0.559 & 1 & 0.955 & 1 & 1 & 1 & 1 \\
\hline
\end{tabular}

scores of India public and private sector banks. The mean constant returns to scale technical efficiency (CRSTE) score of Indian public sector banks over the period 2014-2020 is 0.836 while that of the private sector banks it is 0.912 . We report the CRSTE without mentioning the orientation of the technology assumed. This is due to the fact the both the input and output oriented CRS technical efficiency scores are the same by definition of the constant return to scale. A CRS technology means that increasing (decreasing) inputs by $x \%$ will increase (decrease) output by same $x \%$. So whether we reduce input and keep output constant (input orientation) or we increase output and keep input constant (output orientation) we will attain the same change in the efficiency scores due to the underlying CRS assumption. Hence the mean and median efficiency scores under CRS will be the same. We graphically depict various efficiency measures based on Table 5 in the time series graphs in Fig. 2 below. From these graphs we clearly see that the private sector banks have outperformed the nationalized banks in terms of CRS technological assumption. However, we do not see any unambiguous private ownership advantage when allowing for the variable returns technology to operate. We also find that the private sector banks have higher mean and median scale efficiency as compared to the public sector counterparts.

Our results indicate that the mean and median technical efficiency scores of the public sector bank have consistently been falling from 2014 to 2017 only to rise in the later years. There existed a huge difference in the efficiency scores of the public sector banks pre 2016 when the $\mathrm{AQR}$ was first initiated and consequently almost all of the public sector banks faced surmounting non-performing assets. However, post 2017 the divergence in the efficiency scores was minimized again. This result may be a direct consequence of the mega merger of the SBI Bank and its associates and few other small mergers along with the asset quality review.

Table 6 presents the summary statistics of the regression variables for the second stage DEA where we examine the factors that determine the DEA efficiency scores of Indian banks. In our regression analyses the dependent variables are the CRS technical efficiency scores and the output and input oriented VRS technical efficiency scores. The independent variables are the relative size of the bank, the 

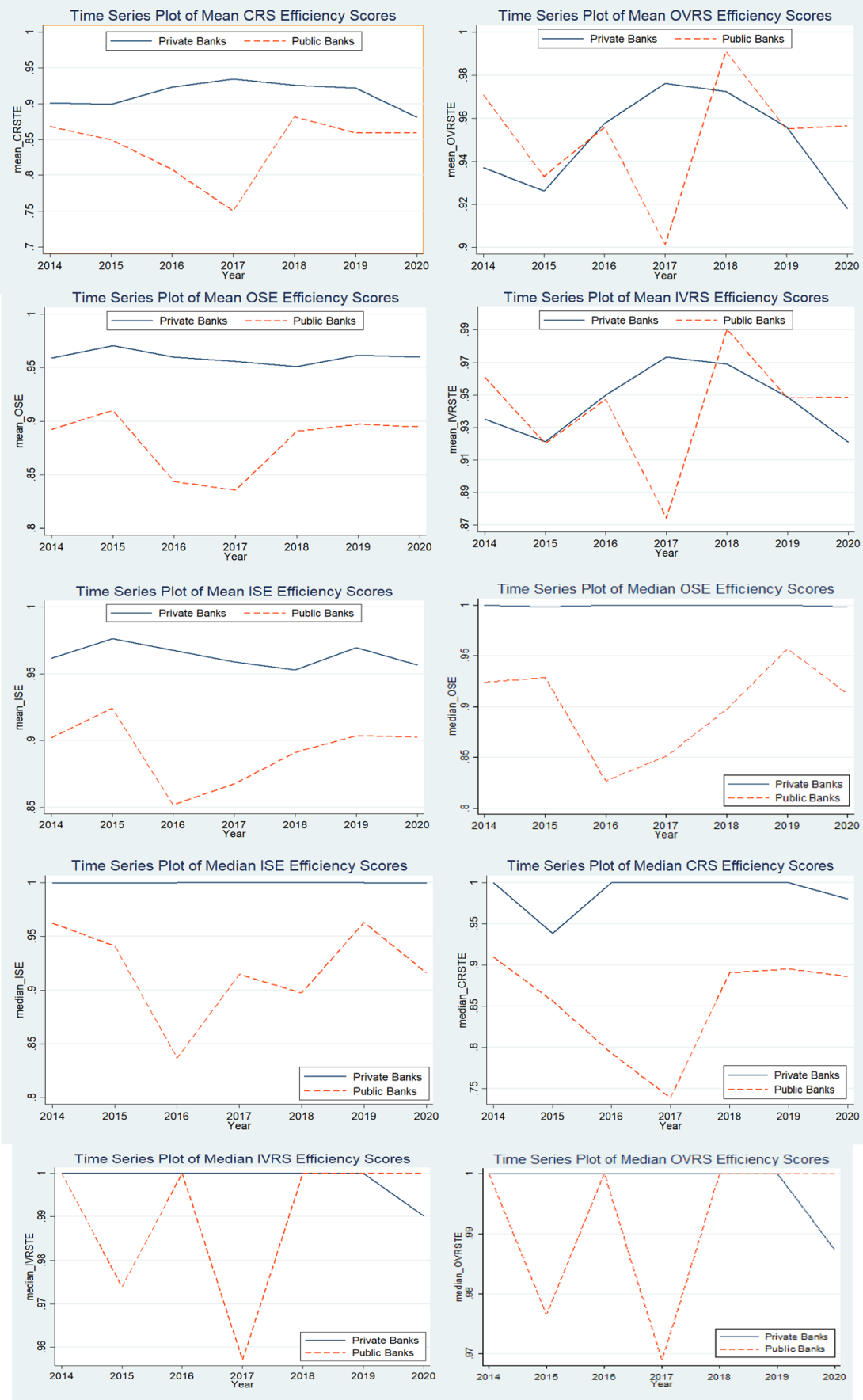

Fig. 2 Time series plots of mean and median DEA efficiency scores 
Table 6 Descriptive statistics of regression variables

\begin{tabular}{|c|c|c|c|c|c|}
\hline Variable & $\mathrm{N}$ & Mean & Std. dev & Min & Max \\
\hline \multicolumn{6}{|l|}{ Dependent variables } \\
\hline CRSTE & 314 & 0.872 & 0.137 & 0.52 & 1 \\
\hline OVRSTE & 314 & 0.95 & 0.085 & 0.606 & 1 \\
\hline IVRSTE & 314 & 0.942 & 0.097 & 0.578 & 1 \\
\hline \multicolumn{6}{|c|}{ Independent variables } \\
\hline Relative size & 314 & 0.022 & 0.034 & 0 & 0.241 \\
\hline Profit & 314 & 355.751 & 4297.014 & $-16,418.031$ & $26,257.315$ \\
\hline Private ownership & 314 & 0.468 & 0.5 & 0 & 1 \\
\hline Net-NPA/advances & 314 & 0.0400716 & 0.03 & 0 & 0.1689 \\
\hline
\end{tabular}

Source: RBI and author's exploration

profits, ownership which is a dummy variable taking a value 1 for the private sector banks and finally we have the proportion of the net NPA as a percentage of total advances of the bank. In our sample data around $47 \%$ of the banks are the private sector banks. The average size of the bank is $2.2 \%$ of the assets of all the scheduled commercial banks. The mean net NPA as a percentage of total advances is around 4\%. Table 7 panel A reports the regression results from Tobit model in the pooled settings where we pool the data on dependent and independent variables for all the years. In the column 1 of Table 7 where regress the CRS technical efficiency scores on the independent variables, we find that the size of the bank as well as the nonperforming assets are detrimental for the efficiency of the banks. They negatively and significantly affect the CRS efficiency scores of Indian banks. We find a significant and negative impact of relative size on the efficiency scores which is in line with the existing literature (Kumar and Gulati 2010; Ariff and Luc 2008). The bad loans also tend to negatively affect the efficiency of Indian banks which is again in line with the existing literature (Das and Ghosh 2006). In addition; our regression results show that the private sector banks tend to have higher CRS efficiency scores as compared to the public sector banks. For the VRS efficiency scores in columns 2 and 3, we do not find any significant differential effect of ownership and NPA on the efficiency scores. Table and panel B presents the results from the random effects Tobit model. Our results show that private ownership of banks increases the mean CRS efficiency score by $8 \%$ than the public ownership. We also find a significant and negative impact of NPAs on the CRS efficiency scores. However, size is no more a significant factor determining the CRS efficiency. None of our regressors do significantly determine the VRS efficiency scores.

\section{Productivity Change: Results from Malmquist Productivity Index}

Table 8 presents the summary of the annual means from the Malmquist productivity index. The average productivity growth for the year 2015 was $4.2 \%(1.042-1 \times 100)$. This change in the total factor productivity has exclusively come from the upward shift in the frontier and a consequent deceleration of the efficiency. From the table, 


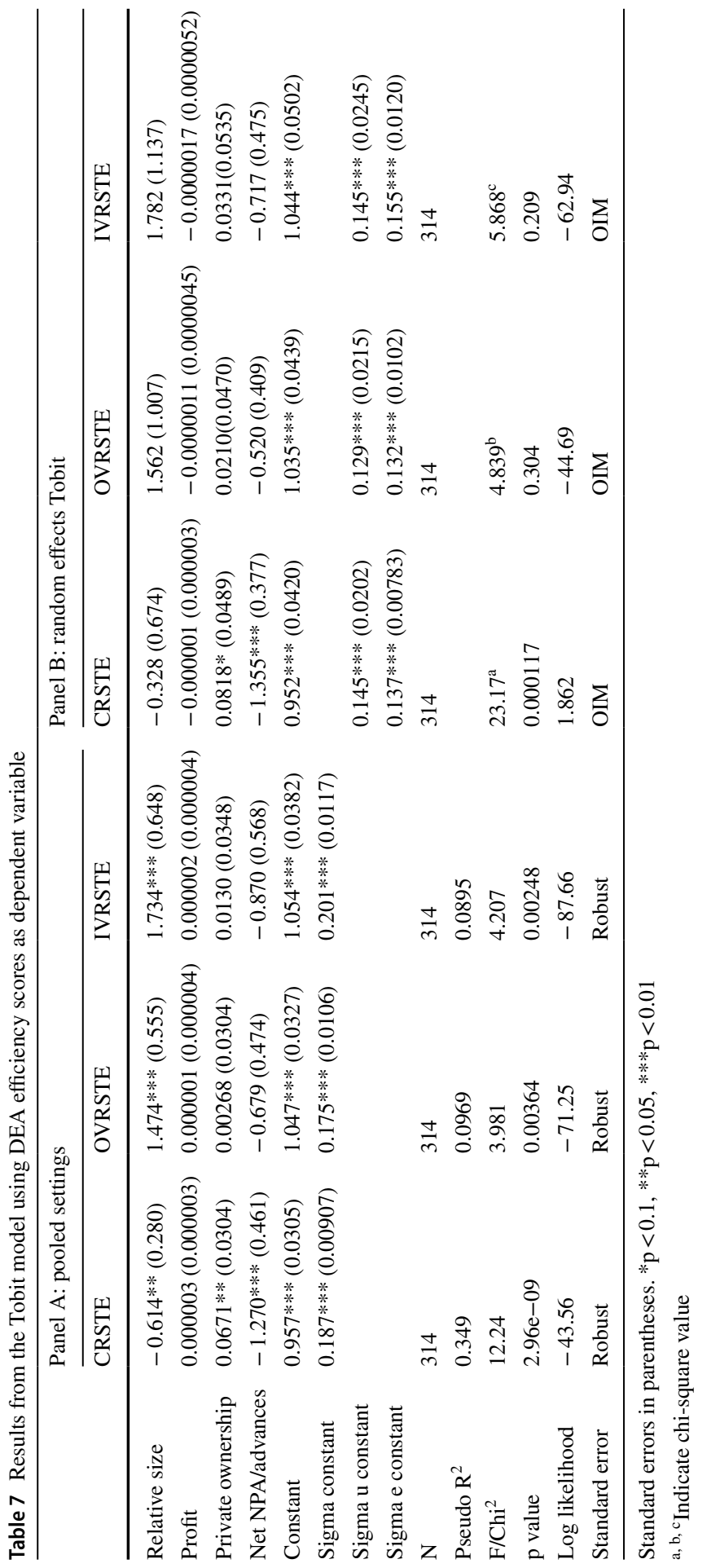


we see a positive TFP change in years 2015, 2017 and 2019 while a negative TFP change occurred in years 2016, 2018 and 2020. The positive TFP changes in years 2015 and 2019 are exclusively a product of the upward shift in the frontier (that is a due to technological change). Except for 2017 and 2018 we see a decline in the technical efficiency. Overall the mean productivity change over the study period of 7 years has been a negative $3.1 \%$ with a corresponding 3\% downward shift in the frontier. The technical efficiency change (due to CRS as well as VRS) has not changed over the sample period. From Table 9 only 7 banks out of 18 public sector banks had a positive TFP growth during the study period. The Bank of Maharashtra, Central Bank of India, Indian Bank, Punjab National Bank, UCO Bank, Union Bank of India and United Bank of India were the public sector banks that experienced positive TFP growth rates among all public sector banks. Apart from the UCO bank and United Bank of India, the TFP growth was brought about by the technical efficiency change alone. Overall only 4 nationalized banks witnessed an upward shift in the production frontier while 7 such banks experienced an improvement in the technical efficiency. In contrast, 6 private banks had a positive TFP growth over the 7 -year study period which was largely due to technological change. Out of 18 private sector banks only 7 banks experienced a fall in the technical efficiency while as many private banks experienced a positive technical change. On average, the Indian public and private sector banks experienced a negative TFP growth bought about exclusively by the downward shift of the frontier.

From Table 10 using 2014 as the base year we find that the 36 public and private sector banks jointly witnessed a fall of $11 \%$ in the TFP growth in the year 2020. This decline in the TFP growth can be attributed to an equivalent fall in the technological progress. The technical efficiency due to CRS did not change while technical efficiency change due to VRS fell by $1 \%$ during the 7-year period.

\section{Stochastic Frontier Analysis (SFA)}

We have used STATA to estimate the frontier production function for measuring different outputs like investments, advances and non-interest income. We are interested in determining the estimated coefficients in the inefficiency model in this study, as they would indicate how banks in India perform. Furthermore, we are also intending to understand the impact of environmental factors on the technical efficiency of the banks. Following Greene (2005) we have adopted true fixed effects model which disentangles time-invariant heterogeneity from time-varying inefficiency. The reason stems from the argument that while observing the output over time and across banks there might be a deviation from the production possibility frontier due to either unobserved time invariant heterogeneity or the technical inefficiency which could be clearly understood if we consider True fixed effects model. In STATA the true fixed effect results in the SFA framework provides maximum likelihood estimates. Thus, in Table 11, MLE results are shown. Estimation results of models with different output variables are presented in Table 11 to understand whether the SFA model established in this study performs well. 
Table 8 Malmquist Index summary of annual means

\begin{tabular}{llllll}
\hline Year & effch & techch & pech & sech & tfpch \\
\hline 2015 & 0.986 & 1.056 & 0.971 & 1.015 & 1.042 \\
2016 & 0.966 & 0.832 & 1.031 & 0.937 & 0.804 \\
2017 & 1.026 & 0.996 & 0.981 & 1.046 & 1.022 \\
2018 & 1.062 & 0.917 & 1.043 & 1.018 & 0.973 \\
2019 & 0.983 & 1.039 & 0.974 & 1.009 & 1.021 \\
2020 & 0.974 & 1.001 & 0.984 & 0.991 & 0.976 \\
Mean & 0.999 & 0.970 & 0.997 & 1.002 & 0.969 \\
\hline
\end{tabular}

Source: Authors' calculations using DEAP Software

In Table 11 we report the results that we have obtained by considering three different outputs-investments, advances and non-interest incomes as stated earlier. Additionally, to explain the frontier we have considered three inputs- capital strength, labour expenses and borrowing. These variables were recognized as inputs in the DEA as well. It is worth mentioning here that we have considered the logarithmic value of the explanatory and dependent variables for the analysis. Apart from this, the literature is divided on the impact of environmental factors influencing the technical inefficiency of the banks. To take into account the variables which are beyond the control of banks nonetheless explaining the technical inefficiency, we have assumed log of NPA, relative size and the ownership. Here, the variable ownership is a dummy which takes up 1 if the bank is public and 0 if it is private.

STATA 14 enables us to incorporate the output oriented SFA in a panel setting with true fixed effects (Greene 2005) under the assumption of truncated normal distribution of the technical inefficiency component. From Table 11 we see that with stable coefficients of parameters, variables like labour expenses and borrowings have passed the significance test at $1 \%$ level denoting a significant positive impact on investments, non-interest incomes and advances. But, as far as the capital strength, which is derived from adding up equity and fixed assets, is concerned it was not found statistically significant when advances and non-interest incomes were considered as output. Now, $m и$ in the table is the dependent variable and is termed as technical inefficiency. Aforementioned, we have considered three variables explaining the variation in the technical inefficiency of the banks. A negative sign of the coefficient explaining $m u$ implies negative impact on the technical inefficiency of the banks therefore; this would have a positive impact on the technical efficiency. In other words, the banks would have become much more efficient owing to the variables having negative sign. Based on the above findings we may conclude that there is a presence of technical inefficiency in the Indian banking sector. As shown in the table, the three main input indicators have significant positive effects on the output of investment. Variables in the technical inefficiency function have significant influence on the output variables. The coefficient of Net NPA (lnnetnpa) is significantly positive when investment was considered as output, which indicates that NPA exerts a positive effect on the technical inefficiency. In contrast, it has a negative impact on 
Table 9 Malmquist Index summary of bank means

\begin{tabular}{|c|c|c|c|c|c|}
\hline Bank & effch & techch & pech & sech & $\mathrm{tfpch}$ \\
\hline Allahabad Bank & 1.02 & 0.976 & 1 & 1.02 & 0.996 \\
\hline Andhra Bank & 0.943 & 0.967 & 0.98 & 0.963 & 0.912 \\
\hline Bank of Baroda & 0.978 & 0.972 & 0.994 & 0.984 & 0.95 \\
\hline Bank of India & 0.969 & 0.985 & 0.998 & 0.971 & 0.954 \\
\hline Bank of Maharashtra & 1.055 & 1.001 & 1.02 & 1.034 & 1.056 \\
\hline Canara Bank & 0.994 & 0.946 & 1 & 0.994 & 0.941 \\
\hline Central Bank of India & 1.106 & 0.976 & 1.017 & 1.087 & 1.079 \\
\hline Corporation Bank & 1 & 0.926 & 1 & 1 & 0.926 \\
\hline Indian Bank & 1.055 & 0.951 & 1 & 1.055 & 1.003 \\
\hline Indian Overseas Bank & 1.05 & 0.935 & 1.037 & 1.012 & 0.982 \\
\hline Oriental Bank of Commerce & 0.948 & 0.953 & 0.965 & 0.982 & 0.903 \\
\hline Punjab and Sind Bank & 0.967 & 0.949 & 0.976 & 0.991 & 0.918 \\
\hline Punjab National Bank & 1.083 & 0.953 & 1 & 1.083 & 1.032 \\
\hline State Bank of India & 0.977 & 0.991 & 1 & 0.977 & 0.968 \\
\hline Syndicate Bank & 0.922 & 1.016 & 0.96 & 0.96 & 0.937 \\
\hline UCO Bank & 1 & 1.014 & 1 & 1 & 1.014 \\
\hline Union Bank of India & 1.06 & 0.97 & 1.019 & 1.04 & 1.028 \\
\hline United Bank of India & 0.986 & 1.025 & 1 & 0.986 & 1.01 \\
\hline Axis Bank & 1 & 0.99 & 1 & 1 & 0.99 \\
\hline City Union Bank Limited & 1 & 1.077 & 1 & 1 & 1.077 \\
\hline Catholic Syrian Bank Ltd. & 1 & 0.908 & 1 & 1 & 0.908 \\
\hline DCB Bank Limited & 0.986 & 0.969 & 0.952 & 1.036 & 0.955 \\
\hline Federal Bank & 1.023 & 1.032 & 1.021 & 1.002 & 1.055 \\
\hline HDFC Bank & 1 & 0.955 & 1 & 1 & 0.955 \\
\hline ICICI Bank & 0.97 & 1.011 & 0.959 & 1.012 & 0.98 \\
\hline IndusInd Bank & 1 & 1.003 & 1 & 1 & 1.003 \\
\hline Jammu \& Kashmir Bank Ltd. & 0.902 & 0.915 & 0.996 & 0.906 & 0.825 \\
\hline Karnataka Bank Ltd. & 0.996 & 0.99 & 0.996 & 1 & 0.986 \\
\hline Karur Vysya Bank & 1.015 & 0.97 & 1.006 & 1.009 & 0.985 \\
\hline Kotak Mahindra Bank Ltd. & 1.023 & 1 & 1.024 & 0.999 & 1.023 \\
\hline Lakshmi Vilas Bank & 0.98 & 0.932 & 0.985 & 0.995 & 0.913 \\
\hline RBL & 0.971 & 0.765 & 0.988 & 0.984 & 0.743 \\
\hline South Indian Bank & 0.98 & 0.954 & 0.989 & 0.99 & 0.934 \\
\hline Tamilnad Mercantile Bank Ltd. & 1 & 1.017 & 1 & 1 & 1.017 \\
\hline Dhanlaxmi Bank & 1.039 & 1.054 & 1.013 & 1.025 & 1.094 \\
\hline Yes Bank Ltd. & 1 & 0.936 & 1 & 1 & 0.936 \\
\hline Mean & 0.999 & 0.97 & 0.997 & 1.002 & 0.969 \\
\hline
\end{tabular}

Source: Authors' calculations using DEAP Software

technical efficiency. Another key finding is that the Relative size has a positive influence on the efficiency of the output. 
Table 10 Malmquist Index summary of annual means 2014 and 20

\begin{tabular}{llllll}
\hline Year & effch & techch & pech & sech & tfpch \\
\hline 2020 & 0.994 & 0.900 & 0.981 & 1.013 & 0.894 \\
\hline
\end{tabular}

Source: Authors' calculations using DEAP Software

We have performed some diagnostic checks which are presented in Table 11. Under $1 \%$ confidence level, the Gamma $(\gamma)$ values are $0.11,0.92$ and 0.84 respectively, which indicate that most of the compound errors are due to technical inefficiency. In other words, technical inefficiency accounts for $11 \%$ variation in investments, $92 \%$ variation in the non-interest incomes and $84 \%$ variation in the advances. Following Kumbhakar et al. (2015) we further calculate the LR statistics to test the technical inefficiency. The restricted model in the table is the typical Cob-Douglas model and the unrestricted model is the stochastic frontier model. The LR statistics in models are 394 and 294 from investments and non-interest incomes respectively. These values are greater than the critical value at a 5\% significance level (Kodde and Palm 1986) implying that the stochastic frontier model is appropriate in the current context for investments and non-interest incomes. In other words, we are strongly rejecting the null-hypothesis of no technical inefficiency. However, in the model with log of advances as dependent variable the value of LR test is less than the critical value thus, SFA is not appropriate in this case. Lambda indicates the ratio of $\sigma_{\mathrm{u}}^{2}$ and $\sigma_{\mathrm{v}}^{2}$ i.e. the relative proportion of one-sided inefficiency to random two-sided noise term (exogenous production shocks). The mean score derived from considering investments, non-interest incomes and advances come out to be $0.91,0.89$ and 0.99 .

Furthermore, before pursuing any stance, it is critical to investigate whether there is a significant difference in the public and private sector banks in India. The rationale to compare the performance of both these categories of banks stem from the fact that where public sector banks have a whooping share of over $60 \%$ of banking assets, the gross NPA is $10.3 \%$ in contrast with private sector banks which have $5.5 \%$. We have performed some parametric and non-parametric tests, the results of which are presented in the Table 11. The application of Kruskal-Wallis equality of population test in our findings underscores a statistically significant variation in the technical efficiency scores of the populations when log of non-interest incomes and advances was considered as output in two distinct cases. Similar results were obtained when t test, Two-sample Wilcoxon rank-sum (Mann-Whitney) test and Kolmogrov-Smirnov test were applied. In other words, we may say that in two out of three cases considered, there is an evidence of heterogeneity in the technical efficiency of private and public sector banks. The evidence of heterogeneity in public and private sector banks was not found when log of investment was considered.

Based on the translog production function and the assumption of truncated normal distribution we have presented the technical efficiency scores in Appendix Table 15. These values range between zero and one. The value of technical efficiency close to zero is a sign of inefficiency subsumed in the statistical noise term and the values close to 1 indicate the degree of efficiency. In addition, we have illustrated 


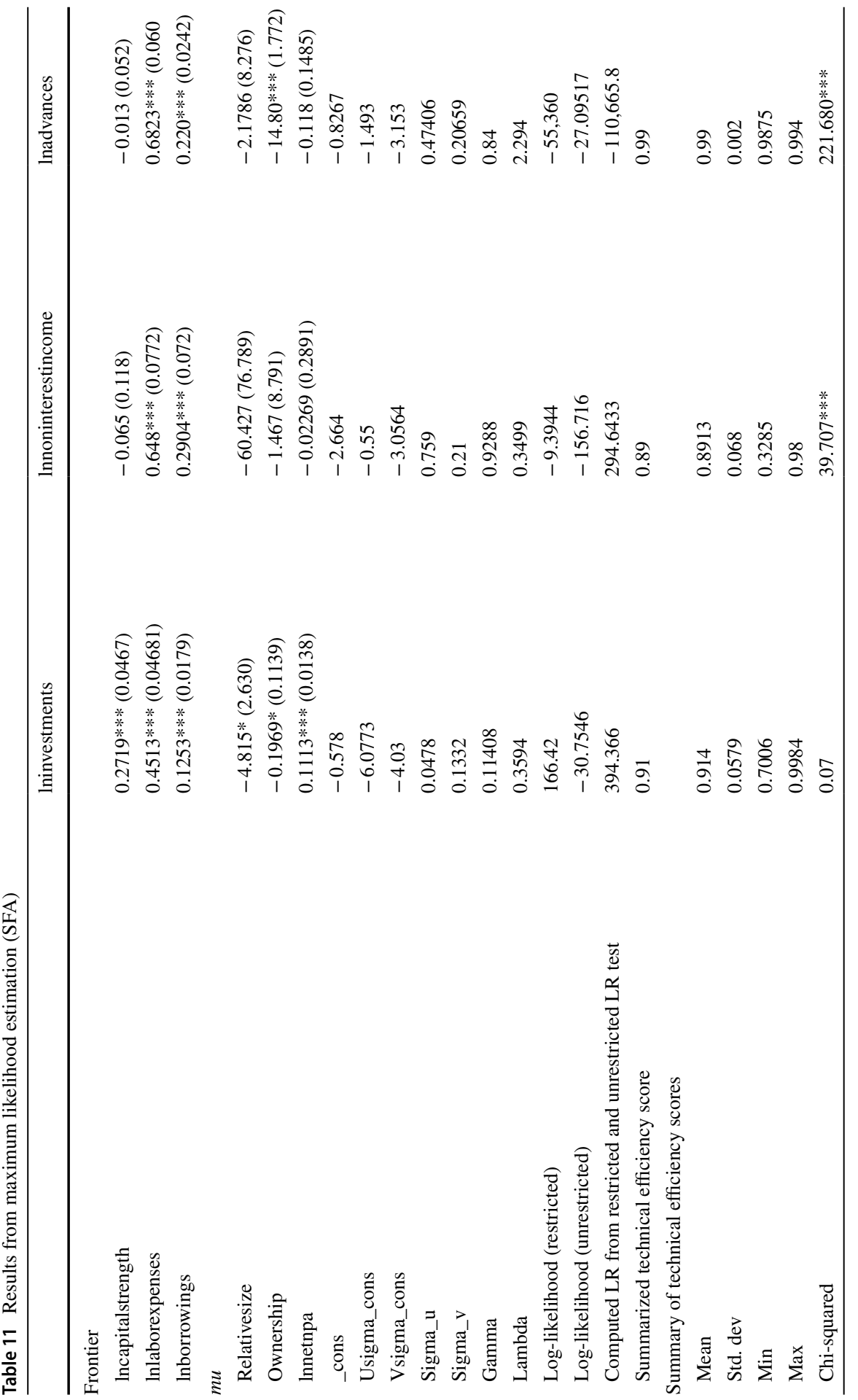




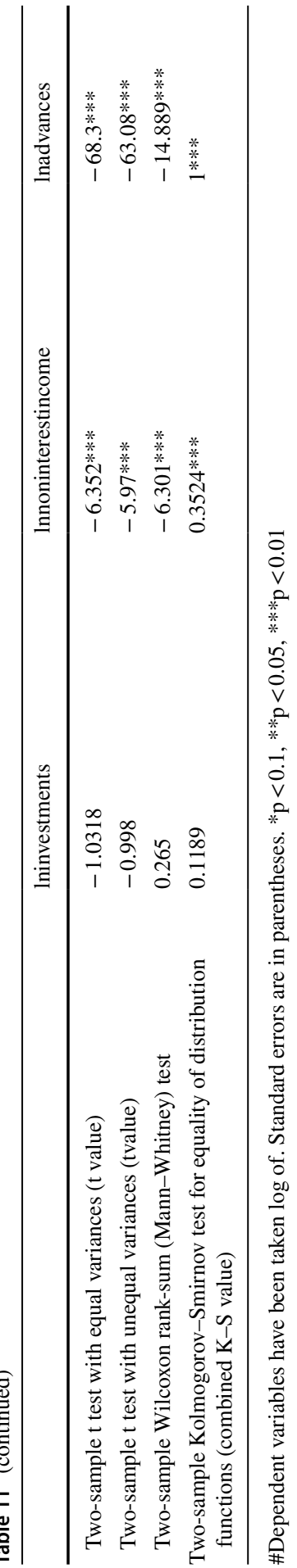


the trajectory of technical efficiency scores of the banks over the analysis period in Fig. 3. It is clear from Fig. 3 that the total number of banks which were highly efficient $(0.91 \leq$ T.E $\leq 1)$ has fallen since 2016 . Considering three cases with different set of outputs like Advances, non-interest income and investments have shown the degree of efficiency of banks in India. The comparison of technical efficiency sores based on three different outputs have unveiled the degree of technical inefficiency in the banking sector indicating that outputs of bank whether it is investment, non-interest incomes or advances could be increased by fixing the factors causing inefficiency.

Table 11 presents the technical efficiency scores based on the first three models with log of investments, non-interest incomes and advances as dependent variable. SFA scores obtained from considering log of investments shows that the technical efficiency scores of the banks in India fell from 0.96 to 0.89 over the period 2014-2017 and then after 2018 it started rising. The change in technical efficiency scores over 2014-2017 is due to a rise in non-performing loans ratio of scheduled commercial and decline in it over 2018-2020 (see Fig. 4). On the other hand, if we look at the technical efficiency scores obtained after considering non-interest incomes as an output variable we find that the scores have kept fluctuation over the period (Table 12).

\section{Conclusion and Policy Implications}

In the Indian context, the burgeoning stream of literature construing the technical efficiency of banks in the context of non-performing assets has gained traction among the scholars. In line with this we endeavour to not only buttress the research conducted in this area but we also bridge the research gap of linking the technical inefficiency caused due to NPA with the ownership of banks in India. We have empirically investigated the effects of undesirable output like NPA on the technical efficiency of banks through parametric and non-parametric methods of production frontier. On an average the public sector banks in our sample not just have higher amount of investments, advances, non-interest incomes, borrowings, fixed assets, labour expenses, equity and NPAs but, these banks also have a high degree of variation in the NPAs in contrast with private sector banks resulting in lower technical efficiency than the private sector banks. DEA unveiled the dichotomy in the technical efficiency of banks. Where the average technical efficiency of public sector banks over the analysis period stood at 0.836 , private sector banks have fared better with the score of 0.912 . This implies that there is a huge potential for the public sector banks to improve their performance. The contrasting results are evident with the fact that private sector banks have higher mean and median scale efficiency as compared to the public sector counterparts. Furthermore, the technical efficiency of banks has plummeted in the period 2014-2017 only to rise in the latter years. The underlying reason is the promulgation of a chain of reforms following the AQR and the merger of State Bank of India with the subsidiary banks to make it a global-sized bank among other mergers. Additionally, from the Tobit analysis we find that the relative size of the bank as well as the non-performing assets as detrimental for the 


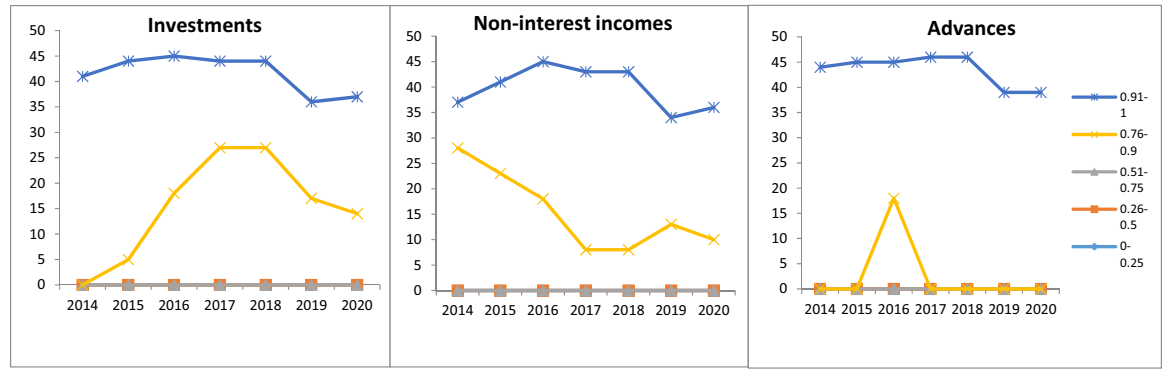

Fig. 3 Time series trend of technical efficiency (SFA)

efficiency of the banks (DEA). They negatively and significantly affect the CRS efficiency scores of Indian banks. The CRS efficiency score of private sector banks is higher as compared to the public sector banks, while we do not find any significant differential effect of ownership and NPA on the VRS efficiency scores. Since CRS efficiency score is an amalgamation of both the pure technical efficiency as well as the scale efficiency, a significant effect of ownership and NPA on CRS efficiency may rightly be explained by the fact that the source of inefficiency in the Indian public sector banks is due to the scale as opposed to the pure technical efficiency. We have demonstrated already this fact that the nationalized banks are less scale efficient than the private sector banks. It is worth mentioning here that private ownership of banks increases the mean CRS efficiency score by $8 \%$ than the public ownership. An important finding is; the size is no more a significant factor determining the CRS efficiency. The results for the Malmquist productivity index reveal that the overall total factor productivity growth has decline over the 7 years starting 2014 . This decline in the TFP growth can largely be attributed to the adverse technological change. Therefore, in order to make the banking system more efficient and vibrant,

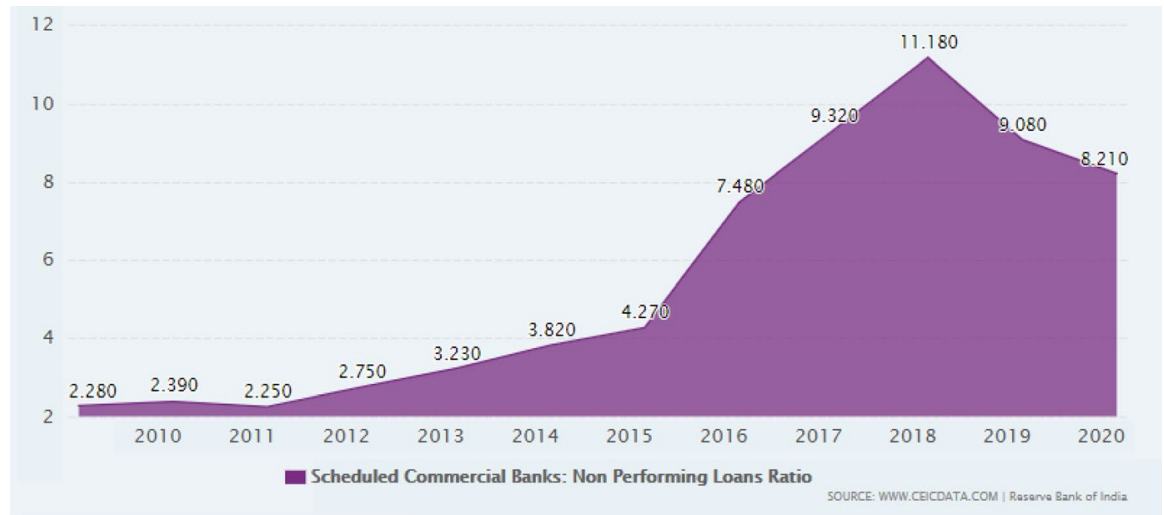

Source: CEIC database RBI

Fig. 4 India's NPA ratio from 1998 to 2020 
Table 12 Change in technical efficiency scores from SFA over 2014-2020

\begin{tabular}{lllll}
\hline Years & te_lninvestments & $\begin{array}{l}\text { te_lnnoninter- } \\
\text { estincome }\end{array}$ & te_lnadvances & $\begin{array}{c}\text { Non-performing loans ratio } \\
\text { of scheduled commercial }\end{array}$ \\
\hline 2014 & 0.96 & 0.85 & 0.99 & 3.820 \\
2015 & 0.94 & 0.88 & 0.99 & 4.270 \\
2016 & 0.91 & 0.87 & 0.99 & 7.480 \\
2017 & 0.89 & 0.92 & 0.99 & 9.320 \\
2018 & 0.89 & 0.91 & 0.99 & 11.18 \\
2019 & 0.90 & 0.90 & 0.99 & 9.18 \\
2020 & 0.90 & 0.91 & 0.99 & 8.21 \\
\hline
\end{tabular}

the banks need to keep up with the new technology viz., the internet banking, the ATMs, the online payment systems and the UPI payments among other technological advancements.

Considering the limitations of DEA to be a non-parametric method, we have corroborated DEA with a parametric method named SFA in our analysis of banks. We have adopted a production function approach with three different output variablesinvestments, advances and non-interest income; three explanatory variables- capital strength, labour expenses and borrowings; three environmental factors affecting the efficiency of banks- NPA, relative size and private ownership. Like DEA, SFA results also show the presence of technical inefficiency in the Indian banking sector. NPA exerts a positive effect on the technical inefficiency when the log of investment was considered as dependent variable. Another key finding is that the Relative size of the bank has a positive influence on the technical efficiency in case of SFA. Additionally, the technical efficiency sores obtained from SFA points towards the heterogeneity in the technical efficiency of private and public sector banks. SFA scores obtained from considering log of investments shows that the technical efficiency scores of the banks in India fell between 2014 and 2017. Post 2008 financial crisis when almost all the countries across the world faced the storm of plummeting growth rates, the banks in India came out unscathed. But, the surge in NPA latter on potentially held the technical efficiency of the banks to ransom as the growth of the banks tapered off with the rise in NPA. However, after 2018 it started rising due to probably the introduction of regulations like AQR and mergers of the banks beyond 2018. The COVID situation may alter the trend seen after 2018. Our future research would delve to incorporate the impact of COVID-19 on the efficiency and productivity of Indian banks. Our SFA results show that the public sector ownership has a positive impact on the efficiency of the banks. This suggests that concerted efforts needs to be taken by the government to improve the efficiency of the public sector banks which has to fulfil broader social and equity objectives in a developing country like India. One direction is through the digitalization and mechanization of the operations of the banks along with performing stress tests to ascertain its vulnerabilities to policy shocks.

The policy directions should be in line with Basel Norms which emphasizes on three pillars of banking regulations concerning with having minimum capital 
requirements (Pillar 1), supervisory review (Pillar 2), and market discipline (Pillar 3 ).Our findings are in conformity with the previous research. Thus, there is a further scope for future research in the sense that the study could be extended to provide insights from a novel methodology called Network DEA, and explore the impact of inclusion of bad outputs like NPA on the technical inefficiency and to what extent the dichotomy prevails in Indian banking sector. The underlying deficiencies in the banking sector could be overcome through a combination of policies targeting the rising NPAs.

\section{Appendix}

See Tables 13, 14 and 15.

Table 13 Descriptive statistics of input and output variables

\begin{tabular}{llllll}
\hline \multicolumn{1}{c}{$\mathrm{N}$} & Mean & SD & Min & Max \\
\hline Ownership: public sector banks & & & & \\
Investments & 167 & $103,403.91$ & $154,036.08$ & 413.335 & $1,060,986.7$ \\
Advances & 167 & $236,385.17$ & $342,469.11$ & 88.531 & $2,325,289.6$ \\
Non-interest income & 167 & 3970.326 & 6713.667 & 2.777 & $45,221.48$ \\
Borrowings & 167 & $30,592.904$ & $61,440.717$ & 0 & $403,017.12$ \\
Fixed assets & 167 & 3831.629 & 6193.447 & 8.961 & $42,918.918$ \\
Labor expenses & 167 & 3844.048 & 6213.202 & 5.502 & $45,714.968$ \\
Equity & 167 & 1099.252 & 1566.985 & 0 & $10,516.69$ \\
Net NPA & 167 & $11,763.846$ & $13,507.342$ & 0 & $110,854.7$ \\
Ownership: private sector & banks & & & & \\
Investments & 147 & $44,200.001$ & $65,761.116$ & 1139.74 & $391,826.66$ \\
Advances & 147 & $113,614.26$ & $174,483.61$ & 2437.043 & $993,702.88$ \\
Non-interest income & 147 & 2912.706 & 4769.668 & 25.945 & $23,260.819$ \\
Borrowings & 147 & $27,352.997$ & $46,688.318$ & 0 & $182,858.62$ \\
Fixed assets & 147 & 1240.895 & 1868.275 & 17.959 & 8410.285 \\
Labor expenses & 147 & 1470.528 & 1870.98 & 63.315 & 9525.668 \\
Equity & 147 & 296.728 & 548.928 & 0 & 2741.921 \\
Net NPA & 147 & 1937.978 & 4083.29 & 0 & $27,823.56$ \\
\hline & & & & & \\
\hline
\end{tabular}


Table 14 DEA efficiency scores

\begin{tabular}{|c|c|c|c|c|c|c|}
\hline Bank name & Year & CRSTE & OVRSTE & IVRSTE & OSE & ISE \\
\hline State Bank of Hyderabad & 2014 & 0.910 & 1.000 & 1.000 & 0.910 & 0.910 \\
\hline Bank of India & 2014 & 0.970 & 1.000 & 1.000 & 0.970 & 0.970 \\
\hline State Bank of Patiala & 2014 & 0.983 & 1.000 & 1.000 & 0.983 & 0.983 \\
\hline Andhra Bank & 2014 & 1.000 & 1.000 & 1.000 & 1.000 & 1.000 \\
\hline Corporation Bank & 2014 & 1.000 & 1.000 & 1.000 & 1.000 & 1.000 \\
\hline Dena Bank & 2014 & 0.906 & 0.983 & 0.982 & 0.921 & 0.922 \\
\hline Vijaya Bank & 2014 & 1.000 & 1.000 & 1.000 & 1.000 & 1.000 \\
\hline Syndicate Bank & 2014 & 0.933 & 0.972 & 0.969 & 0.960 & 0.962 \\
\hline Union Bank of India & 2014 & 0.706 & 0.888 & 0.820 & 0.795 & 0.861 \\
\hline Punjab National Bank & 2014 & 0.590 & 1.000 & 1.000 & 0.590 & 0.590 \\
\hline United Bank of India & 2014 & 0.924 & 1.000 & 1.000 & 0.924 & 0.924 \\
\hline UCO Bank & 2014 & 1.000 & 1.000 & 1.000 & 1.000 & 1.000 \\
\hline State Bank of Bikaner \& Jaipur & 2014 & 1.000 & 1.000 & 1.000 & 1.000 & 1.000 \\
\hline State Bank of Mysore & 2014 & 0.876 & 0.885 & 0.876 & 0.990 & 1.000 \\
\hline Indian Overseas Bank & 2014 & 0.671 & 0.765 & 0.696 & 0.877 & 0.964 \\
\hline IDBI Bank Limited & 2014 & 1.000 & 1.000 & 1.000 & 1.000 & 1.000 \\
\hline Canara Bank & 2014 & 0.835 & 1.000 & 1.000 & 0.835 & 0.835 \\
\hline Indian Bank & 2014 & 0.708 & 1.000 & 1.000 & 0.708 & 0.708 \\
\hline Punjab and Sind Bank & 2014 & 0.816 & 1.000 & 1.000 & 0.816 & 0.816 \\
\hline Allahabad Bank & 2014 & 0.765 & 0.970 & 0.950 & 0.789 & 0.806 \\
\hline State Bank of Travancore & 2014 & 0.954 & 0.991 & 0.990 & 0.963 & 0.964 \\
\hline Bharatiya Mahila Bank Ltd. & 2014 & 1.000 & 1.000 & 1.000 & 1.000 & 1.000 \\
\hline State Bank of India & 2014 & 0.772 & 1.000 & 1.000 & 0.772 & 0.772 \\
\hline Central Bank of India & 2014 & 0.520 & 0.902 & 0.828 & 0.576 & 0.628 \\
\hline Bank of Baroda & 2014 & 1.000 & 1.000 & 1.000 & 1.000 & 1.000 \\
\hline Oriental Bank of Commerce & 2014 & 0.900 & 1.000 & 1.000 & 0.900 & 0.900 \\
\hline Bank of Maharashtra & 2014 & 0.701 & 0.857 & 0.835 & 0.818 & 0.839 \\
\hline Catholic Syrian Bank Ltd. & 2014 & 0.712 & 1.000 & 1.000 & 0.712 & 0.712 \\
\hline HDFC Bank & 2014 & 1.000 & 1.000 & 1.000 & 1.000 & 1.000 \\
\hline DCB Bank Limited & 2014 & 1.000 & 1.000 & 1.000 & 1.000 & 1.000 \\
\hline Karnataka Bank Ltd. & 2014 & 1.000 & 1.000 & 1.000 & 1.000 & 1.000 \\
\hline IndusInd Bank & 2014 & 1.000 & 1.000 & 1.000 & 1.000 & 1.000 \\
\hline RBL & 2014 & 1.000 & 1.000 & 1.000 & 1.000 & 1.000 \\
\hline Karur Vysya Bank & 2014 & 0.916 & 0.920 & 0.921 & 0.995 & 0.995 \\
\hline Lakshmi Vilas Bank & 2014 & 0.811 & 0.848 & 0.844 & 0.956 & 0.960 \\
\hline City Union Bank Limited & 2014 & 1.000 & 1.000 & 1.000 & 1.000 & 1.000 \\
\hline ICICI Bank & 2014 & 0.899 & 1.000 & 1.000 & 0.899 & 0.899 \\
\hline Dhanlaxmi Bank & 2014 & 0.645 & 0.781 & 0.768 & 0.827 & 0.840 \\
\hline Nainital Bank & 2014 & 1.000 & 1.000 & 1.000 & 1.000 & 1.000 \\
\hline Tamilnad Mercantile Bank Ltd. & 2014 & 1.000 & 1.000 & 1.000 & 1.000 & 1.000 \\
\hline YES Bank Ltd. & 2014 & 1.000 & 1.000 & 1.000 & 1.000 & 1.000 \\
\hline Jammu \& Kashmir Bank Ltd. & 2014 & 1.000 & 1.000 & 1.000 & 1.000 & 1.000 \\
\hline ING Vysya Bank & 2014 & 0.622 & 0.702 & 0.687 & 0.886 & 0.905 \\
\hline Kotak Mahindra Bank Ltd. & 2014 & 0.651 & 0.701 & 0.697 & 0.929 & 0.934 \\
\hline
\end{tabular}


Table 14 (continued)

\begin{tabular}{|c|c|c|c|c|c|c|}
\hline Bank name & Year & CRSTE & OVRSTE & IVRSTE & OSE & ISE \\
\hline Axis Bank & 2014 & 1.000 & 1.000 & 1.000 & 1.000 & 1.000 \\
\hline Federal Bank & 2014 & 0.863 & 0.883 & 0.878 & 0.978 & 0.984 \\
\hline South Indian Bank & 2014 & 0.907 & 0.909 & 0.907 & 0.998 & 1.000 \\
\hline Central Bank of India & 2015 & 0.641 & 0.805 & 0.700 & 0.797 & 0.916 \\
\hline Syndicate Bank & 2015 & 0.979 & 0.979 & 0.979 & 1.000 & 1.000 \\
\hline Andhra Bank & 2015 & 0.760 & 0.760 & 0.761 & 1.000 & 0.999 \\
\hline Indian BaNK & 2015 & 0.860 & 1.000 & 1.000 & 0.860 & 0.860 \\
\hline Allahabad Bank & 2015 & 0.723 & 0.824 & 0.803 & 0.877 & 0.900 \\
\hline Punjab and Sind Bank & 2015 & 0.809 & 0.950 & 0.942 & 0.851 & 0.859 \\
\hline State Bank of Patiala & 2015 & 0.853 & 0.918 & 0.915 & 0.928 & 0.932 \\
\hline State Bank of Travancore & 2015 & 0.875 & 1.000 & 1.000 & 0.875 & 0.875 \\
\hline Dena Bank & 2015 & 0.835 & 0.965 & 0.958 & 0.865 & 0.872 \\
\hline United Bank of India & 2015 & 1.000 & 1.000 & 1.000 & 1.000 & 1.000 \\
\hline State Bank of Bikaner \& Jaipur & 2015 & 0.902 & 0.956 & 0.954 & 0.944 & 0.946 \\
\hline Bharatiya Mahila Bank Ltd. & 2015 & 1.000 & 1.000 & 1.000 & 1.000 & 1.000 \\
\hline IDBI Bank Limited & 2015 & 1.000 & 1.000 & 1.000 & 1.000 & 1.000 \\
\hline Corporation Bank & 2015 & 1.000 & 1.000 & 1.000 & 1.000 & 1.000 \\
\hline Oriental Bank of Commerce & 2015 & 1.000 & 1.000 & 1.000 & 1.000 & 1.000 \\
\hline Vijaya Bank & 2015 & 1.000 & 1.000 & 1.000 & 1.000 & 1.000 \\
\hline Indian Overseas Bank & 2015 & 0.692 & 0.856 & 0.808 & 0.808 & 0.855 \\
\hline Bank of Maharashtra & 2015 & 0.696 & 0.758 & 0.739 & 0.917 & 0.941 \\
\hline Canara Bank & 2015 & 0.908 & 1.000 & 1.000 & 0.908 & 0.908 \\
\hline Punjab National Bank & 2015 & 0.605 & 0.976 & 0.967 & 0.620 & 0.626 \\
\hline UCO Bank & 2015 & 1.000 & 1.000 & 1.000 & 1.000 & 1.000 \\
\hline State Bank of Hyderabad & 2015 & 0.856 & 0.977 & 0.974 & 0.877 & 0.879 \\
\hline State Bank of India & 2015 & 0.733 & 1.000 & 1.000 & 0.733 & 0.733 \\
\hline Bank of India & 2015 & 0.768 & 0.920 & 0.878 & 0.834 & 0.875 \\
\hline Bank of Baroda & 2015 & 1.000 & 1.000 & 1.000 & 1.000 & 1.000 \\
\hline State Bank of Mysore & 2015 & 0.769 & 0.815 & 0.784 & 0.943 & 0.982 \\
\hline Union Bank of India & 2015 & 0.680 & 0.727 & 0.682 & 0.935 & 0.998 \\
\hline ING Vysya Bank & 2015 & 0.603 & 0.606 & 0.604 & 0.996 & 0.999 \\
\hline Dhanlaxmi Bank & 2015 & 0.687 & 0.704 & 0.699 & 0.976 & 0.984 \\
\hline RBL & 2015 & 1.000 & 1.000 & 1.000 & 1.000 & 1.000 \\
\hline South Indian Bank & 2015 & 0.794 & 0.880 & 0.856 & 0.903 & 0.928 \\
\hline YES Bank Ltd. & 2015 & 1.000 & 1.000 & 1.000 & 1.000 & 1.000 \\
\hline Lakshmi Vilas Bank & 2015 & 0.854 & 0.854 & 0.856 & 0.999 & 0.998 \\
\hline Axis Bank & 2015 & 1.000 & 1.000 & 1.000 & 1.000 & 1.000 \\
\hline Nainital Bank & 2015 & 1.000 & 1.000 & 1.000 & 1.000 & 1.000 \\
\hline Catholic Syrian Bank Ltd. & 2015 & 0.922 & 1.000 & 1.000 & 0.922 & 0.922 \\
\hline Kotak Mahindra Bank Ltd. & 2015 & 0.707 & 0.745 & 0.725 & 0.950 & 0.975 \\
\hline Karur Vysya Bank & 2015 & 0.856 & 0.876 & 0.856 & 0.978 & 1.000 \\
\hline ICICI Bank & 2015 & 0.955 & 1.000 & 1.000 & 0.955 & 0.955 \\
\hline Jammu \& Kashmir Bank Ltd. & 2015 & 0.825 & 0.917 & 0.901 & 0.900 & 0.915 \\
\hline DCB Bank Limited & 2015 & 1.000 & 1.000 & 1.000 & 1.000 & 1.000 \\
\hline
\end{tabular}


Table 14 (continued)

\begin{tabular}{|c|c|c|c|c|c|c|}
\hline Bank name & Year & CRSTE & OVRSTE & IVRSTE & OSE & ISE \\
\hline HDFC Bank & 2015 & 1.000 & 1.000 & 1.000 & 1.000 & 1.000 \\
\hline Federal Bank & 2015 & 0.868 & 1.000 & 1.000 & 0.868 & 0.868 \\
\hline Tamilnad Mercantile Bank Ltd. & 2015 & 1.000 & 1.000 & 1.000 & 1.000 & 1.000 \\
\hline City Union Bank Limited & 2015 & 1.000 & 1.000 & 1.000 & 1.000 & 1.000 \\
\hline IndusInd Bank & 2015 & 1.000 & 1.000 & 1.000 & 1.000 & 1.000 \\
\hline Karnataka Bank Ltd. & 2015 & 0.913 & 0.944 & 0.931 & 0.967 & 0.981 \\
\hline Allahabad Bank & 2016 & 0.701 & 0.800 & 0.785 & 0.877 & 0.893 \\
\hline Dena Bank & 2016 & 0.658 & 0.814 & 0.780 & 0.809 & 0.844 \\
\hline Indian Overseas Bank & 2016 & 0.542 & 0.753 & 0.655 & 0.719 & 0.827 \\
\hline Andhra Bank & 2016 & 0.848 & 1.000 & 1.000 & 0.848 & 0.848 \\
\hline Canara Bank & 2016 & 0.793 & 1.000 & 1.000 & 0.793 & 0.793 \\
\hline State Bank of Bikaner And Jaipur & 2016 & 1.000 & 1.000 & 1.000 & 1.000 & 1.000 \\
\hline State Bank of Travancore & 2016 & 1.000 & 1.000 & 1.000 & 1.000 & 1.000 \\
\hline State Bank of Mysore & 2016 & 0.670 & 1.000 & 1.000 & 0.670 & 0.670 \\
\hline Bank of Baroda & 2016 & 0.761 & 1.000 & 1.000 & 0.761 & 0.761 \\
\hline State Bank of Patiala & 2016 & 0.742 & 0.898 & 0.887 & 0.827 & 0.837 \\
\hline Bharatiya Mahila Bank Ltd. & 2016 & 1.000 & 1.000 & 1.000 & 1.000 & 1.000 \\
\hline IDBI Bank Limited & 2016 & 1.000 & 1.000 & 1.000 & 1.000 & 1.000 \\
\hline Punjab and SIND Bank & 2016 & 0.884 & 1.000 & 1.000 & 0.884 & 0.884 \\
\hline UCO Bank & 2016 & 1.000 & 1.000 & 1.000 & 1.000 & 1.000 \\
\hline State Bank of India & 2016 & 0.801 & 1.000 & 1.000 & 0.801 & 0.801 \\
\hline Bank of Maharashtra & 2016 & 0.696 & 0.945 & 0.938 & 0.736 & 0.742 \\
\hline Central Bank of India & 2016 & 0.580 & 1.000 & 1.000 & 0.580 & 0.580 \\
\hline Vijaya Bank & 2016 & 0.863 & 0.899 & 0.895 & 0.960 & 0.965 \\
\hline Punjab National Bank & 2016 & 0.680 & 0.961 & 0.948 & 0.708 & 0.718 \\
\hline Syndicate Bank & 2016 & 0.765 & 0.964 & 0.957 & 0.793 & 0.799 \\
\hline Corporation Bank & 2016 & 1.000 & 1.000 & 1.000 & 1.000 & 1.000 \\
\hline United Bank of India & 2016 & 0.766 & 1.000 & 1.000 & 0.766 & 0.766 \\
\hline Bank of India & 2016 & 0.661 & 0.869 & 0.850 & 0.760 & 0.777 \\
\hline State Bank of Hyderabad & 2016 & 0.995 & 1.000 & 1.000 & 0.995 & 0.995 \\
\hline Indian Bank & 2016 & 0.875 & 1.000 & 1.000 & 0.875 & 0.875 \\
\hline Union Bank of India & 2016 & 0.713 & 0.904 & 0.885 & 0.788 & 0.805 \\
\hline Oriental Bank of Commerce & 2016 & 0.828 & 1.000 & 1.000 & 0.828 & 0.828 \\
\hline Axis Bank Limited & 2016 & 1.000 & 1.000 & 1.000 & 1.000 & 1.000 \\
\hline South Indian Bank Ltd. & 2016 & 0.723 & 0.834 & 0.785 & 0.867 & 0.921 \\
\hline Karnataka Bank Ltd. & 2016 & 1.000 & 1.000 & 1.000 & 1.000 & 1.000 \\
\hline Lakshmi Vilas Bank Ltd. & 2016 & 0.924 & 0.929 & 0.933 & 0.994 & 0.990 \\
\hline Bandhan Bank Limited & 2016 & 1.000 & 1.000 & 1.000 & 1.000 & 1.000 \\
\hline City Union Bank Limited & 2016 & 1.000 & 1.000 & 1.000 & 1.000 & 1.000 \\
\hline ICICI Bank Limited & 2016 & 1.000 & 1.000 & 1.000 & 1.000 & 1.000 \\
\hline Karur Vysya Bank Ltd. & 2016 & 1.000 & 1.000 & 1.000 & 1.000 & 1.000 \\
\hline Federal Bank Ltd. & 2016 & 0.796 & 0.935 & 0.911 & 0.852 & 0.874 \\
\hline IndusInd Bank Ltd. & 2016 & 1.000 & 1.000 & 1.000 & 1.000 & 1.000 \\
\hline The Dhanalakshmi Bank Ltd. & 2016 & 0.752 & 0.765 & 0.753 & 0.984 & 0.999 \\
\hline
\end{tabular}


Table 14 (continued)

\begin{tabular}{|c|c|c|c|c|c|c|}
\hline Bank name & Year & CRSTE & OVRSTE & IVRSTE & OSE & ISE \\
\hline Hdfc Bank Ltd. & 2016 & 1.000 & 1.000 & 1.000 & 1.000 & 1.000 \\
\hline DCB Bank Limited & 2016 & 0.929 & 0.991 & 0.989 & 0.938 & 0.939 \\
\hline Tamilnad Mercantile Bank Ltd. & 2016 & 1.000 & 1.000 & 1.000 & 1.000 & 1.000 \\
\hline IDFC First Bank Limited & 2016 & 1.000 & 1.000 & 1.000 & 1.000 & 1.000 \\
\hline RBL Bank Limited & 2016 & 1.000 & 1.000 & 1.000 & 1.000 & 1.000 \\
\hline Nainital Bank Ltd. & 2016 & 1.000 & 1.000 & 1.000 & 1.000 & 1.000 \\
\hline Jammu \& Kashmir Bank Ltd. & 2016 & 0.604 & 0.822 & 0.765 & 0.735 & 0.790 \\
\hline Kotak Mahindra Bank Ltd. & 2016 & 0.656 & 0.832 & 0.814 & 0.789 & 0.806 \\
\hline Yes Bank Ltd. & 2016 & 1.000 & 1.000 & 1.000 & 1.000 & 1.000 \\
\hline CSB Bank Limited & 2016 & 1.000 & 1.000 & 1.000 & 1.000 & 1.000 \\
\hline Indian Overseas Bank & 2017 & 0.555 & 0.751 & 0.578 & 0.740 & 0.961 \\
\hline Punjab And Sind Bank & 2017 & 0.749 & 0.816 & 0.758 & 0.918 & 0.988 \\
\hline Andhra Bank & 2017 & 0.761 & 0.906 & 0.889 & 0.840 & 0.856 \\
\hline Syndicate Bank & 2017 & 0.655 & 1.000 & 1.000 & 0.655 & 0.655 \\
\hline UCO Bank & 2017 & 0.940 & 1.000 & 1.000 & 0.940 & 0.940 \\
\hline Bharatiya Mahila Bank Ltd. & 2017 & 0.664 & 1.000 & 1.000 & 0.664 & 0.664 \\
\hline Dena Bank & 2017 & 0.698 & 0.796 & 0.746 & 0.877 & 0.936 \\
\hline Bank of Maharashtra & 2017 & 0.604 & 0.743 & 0.705 & 0.813 & 0.857 \\
\hline Oriental Bank of Commerce & 2017 & 0.785 & 0.815 & 0.785 & 0.963 & 1.000 \\
\hline State Bank of India & 2017 & 0.747 & 1.000 & 1.000 & 0.747 & 0.747 \\
\hline State Bank of Travancore & 2017 & 0.732 & 1.000 & 1.000 & 0.732 & 0.732 \\
\hline State Bank of Patiala & 2017 & 0.576 & 0.676 & 0.616 & 0.851 & 0.935 \\
\hline Indian Bank & 2017 & 0.893 & 0.978 & 0.976 & 0.913 & 0.915 \\
\hline Punjab National Bank & 2017 & 0.821 & 1.000 & 1.000 & 0.821 & 0.821 \\
\hline Allahabad Bank & 2017 & 0.703 & 0.731 & 0.703 & 0.962 & 0.999 \\
\hline Bank of India & 2017 & 0.739 & 0.875 & 0.819 & 0.844 & 0.902 \\
\hline Corporation Bank & 2017 & 1.000 & 1.000 & 1.000 & 1.000 & 1.000 \\
\hline Bank of Baroda & 2017 & 0.922 & 1.000 & 1.000 & 0.922 & 0.922 \\
\hline Canara Bank & 2017 & 0.774 & 0.969 & 0.957 & 0.798 & 0.808 \\
\hline IDBI Bank Limited & 2017 & 0.897 & 0.989 & 0.987 & 0.907 & 0.909 \\
\hline Union Bank of India & 2017 & 0.873 & 0.931 & 0.924 & 0.938 & 0.945 \\
\hline State Bank of Mysore & 2017 & 0.549 & 0.836 & 0.744 & 0.657 & 0.739 \\
\hline United Bank of India & 2017 & 0.924 & 1.000 & 1.000 & 0.924 & 0.924 \\
\hline Central Bank of India & 2017 & 0.601 & 1.000 & 1.000 & 0.601 & 0.601 \\
\hline State Bank of Bikaner And Jaipur & 2017 & 0.732 & 1.000 & 1.000 & 0.732 & 0.732 \\
\hline Vijaya Bank & 2017 & 0.712 & 0.780 & 0.735 & 0.913 & 0.968 \\
\hline State Bank of Hyderabad & 2017 & 0.663 & 0.745 & 0.682 & 0.890 & 0.973 \\
\hline The Dhanalakshmi Bank Ltd. & 2017 & 0.776 & 0.900 & 0.844 & 0.862 & 0.920 \\
\hline Karnataka Bank Ltd. & 2017 & 1.000 & 1.000 & 1.000 & 1.000 & 1.000 \\
\hline Bandhan Bank Limited & 2017 & 1.000 & 1.000 & 1.000 & 1.000 & 1.000 \\
\hline Nainital Bank Ltd. & 2017 & 1.000 & 1.000 & 1.000 & 1.000 & 1.000 \\
\hline Jammu \& Kashmir Bank Ltd. & 2017 & 0.633 & 1.000 & 1.000 & 0.633 & 0.633 \\
\hline Federal Bank Ltd. & 2017 & 0.989 & 1.000 & 1.000 & 0.989 & 0.989 \\
\hline South Indian Bank Ltd. & 2017 & 0.981 & 1.000 & 1.000 & 0.981 & 0.981 \\
\hline
\end{tabular}


Table 14 (continued)

\begin{tabular}{|c|c|c|c|c|c|c|}
\hline Bank name & Year & CRSTE & OVRSTE & IVRSTE & OSE & ISE \\
\hline Karur Vysya Bank Ltd. & 2017 & 0.873 & 1.000 & 1.000 & 0.873 & 0.873 \\
\hline DCB Bank Limited & 2017 & 0.923 & 0.942 & 0.941 & 0.979 & 0.980 \\
\hline City Union Bank Limited & 2017 & 1.000 & 1.000 & 1.000 & 1.000 & 1.000 \\
\hline Axis Bank Limited & 2017 & 1.000 & 1.000 & 1.000 & 1.000 & 1.000 \\
\hline HDFC Bank Ltd. & 2017 & 1.000 & 1.000 & 1.000 & 1.000 & 1.000 \\
\hline RBL Bank Limited & 2017 & 0.856 & 0.907 & 0.915 & 0.943 & 0.935 \\
\hline Yes Bank Ltd. & 2017 & 1.000 & 1.000 & 1.000 & 1.000 & 1.000 \\
\hline Lakshmi Vilas Bank Ltd. & 2017 & 0.887 & 0.909 & 0.915 & 0.975 & 0.969 \\
\hline IndusInd Bank Ltd. & 2017 & 1.000 & 1.000 & 1.000 & 1.000 & 1.000 \\
\hline Kotak Mahindra Bank Ltd. & 2017 & 0.709 & 0.843 & 0.828 & 0.840 & 0.856 \\
\hline IDFC First Bank Limited & 2017 & 1.000 & 1.000 & 1.000 & 1.000 & 1.000 \\
\hline CSB Bank Limited & 2017 & 1.000 & 1.000 & 1.000 & 1.000 & 1.000 \\
\hline ICICI Bank Limited & 2017 & 1.000 & 1.000 & 1.000 & 1.000 & 1.000 \\
\hline Tamilnad Mercantile Bank Ltd. & 2017 & 1.000 & 1.000 & 1.000 & 1.000 & 1.000 \\
\hline Punjab and Sind Bank & 2018 & 0.890 & 1.000 & 1.000 & 0.890 & 0.890 \\
\hline State Bank of India & 2018 & 0.846 & 1.000 & 1.000 & 0.846 & 0.846 \\
\hline Union Bank of India & 2018 & 1.000 & 1.000 & 1.000 & 1.000 & 1.000 \\
\hline Oriental Bank of Commerce & 2018 & 1.000 & 1.000 & 1.000 & 1.000 & 1.000 \\
\hline UCO Bank & 2018 & 1.000 & 1.000 & 1.000 & 1.000 & 1.000 \\
\hline Allahabad Bank & 2018 & 0.829 & 0.841 & 0.831 & 0.986 & 0.997 \\
\hline Corporation Bank & 2018 & 1.000 & 1.000 & 1.000 & 1.000 & 1.000 \\
\hline IDBI Bank Limited & 2018 & 1.000 & 1.000 & 1.000 & 1.000 & 1.000 \\
\hline Indian Overseas Bank & 2018 & 0.752 & 1.000 & 1.000 & 0.752 & 0.752 \\
\hline Central Bank of India & 2018 & 0.897 & 1.000 & 1.000 & 0.897 & 0.897 \\
\hline Vijaya Bank & 2018 & 0.868 & 1.000 & 1.000 & 0.868 & 0.868 \\
\hline Canara Bank & 2018 & 0.778 & 1.000 & 1.000 & 0.778 & 0.778 \\
\hline Bank of Maharashtra & 2018 & 0.857 & 1.000 & 1.000 & 0.857 & 0.857 \\
\hline Dena Bank & 2018 & 0.776 & 1.000 & 1.000 & 0.776 & 0.776 \\
\hline Andhra Bank & 2018 & 0.975 & 1.000 & 1.000 & 0.975 & 0.975 \\
\hline Syndicate Bank & 2018 & 0.713 & 1.000 & 1.000 & 0.713 & 0.713 \\
\hline Indian Bank & 2018 & 0.946 & 1.000 & 1.000 & 0.946 & 0.946 \\
\hline Bank of Baroda & 2018 & 0.992 & 1.000 & 1.000 & 0.992 & 0.992 \\
\hline Punjab National Bank & 2018 & 0.635 & 1.000 & 1.000 & 0.635 & 0.635 \\
\hline United Bank of India & 2018 & 0.977 & 1.000 & 1.000 & 0.977 & 0.977 \\
\hline Bank of India & 2018 & 0.790 & 0.971 & 0.968 & 0.813 & 0.816 \\
\hline CSB Bank Limited & 2018 & 0.797 & 1.000 & 1.000 & 0.797 & 0.797 \\
\hline Tamilnad Mercantile Bank Ltd. & 2018 & 1.000 & 1.000 & 1.000 & 1.000 & 1.000 \\
\hline Yes Bank Ltd. & 2018 & 1.000 & 1.000 & 1.000 & 1.000 & 1.000 \\
\hline IndusInd bank Ltd. & 2018 & 1.000 & 1.000 & 1.000 & 1.000 & 1.000 \\
\hline South Indian Bank Ltd. & 2018 & 0.873 & 0.909 & 0.899 & 0.960 & 0.971 \\
\hline The Dhanalakshmi Bank Ltd. & 2018 & 1.000 & 1.000 & 1.000 & 1.000 & 1.000 \\
\hline Axis Bank Limited & 2018 & 1.000 & 1.000 & 1.000 & 1.000 & 1.000 \\
\hline Lakshmi Vilas Bank Ltd. & 2018 & 0.759 & 0.798 & 0.817 & 0.951 & 0.929 \\
\hline RBL Bank Limited & 2018 & 0.860 & 0.908 & 0.916 & 0.947 & 0.938 \\
\hline
\end{tabular}


Table 14 (continued)

\begin{tabular}{|c|c|c|c|c|c|c|}
\hline Bank name & Year & CRSTE & OVRSTE & IVRSTE & OSE & ISE \\
\hline HDFC Bank Ltd. & 2018 & 1.000 & 1.000 & 1.000 & 1.000 & 1.000 \\
\hline Karur Vysya Bank Ltd. & 2018 & 0.862 & 0.942 & 0.920 & 0.915 & 0.937 \\
\hline City Union Bank Limited & 2018 & 1.000 & 1.000 & 1.000 & 1.000 & 1.000 \\
\hline Kotak Mahindra Bank Ltd. & 2018 & 0.834 & 1.000 & 1.000 & 0.834 & 0.834 \\
\hline Karnataka Bank Ltd. & 2018 & 1.000 & 1.000 & 1.000 & 1.000 & 1.000 \\
\hline ICICI Bank Limited & 2018 & 1.000 & 1.000 & 1.000 & 1.000 & 1.000 \\
\hline DCB Bank Limited & 2018 & 0.894 & 0.914 & 0.917 & 0.979 & 0.975 \\
\hline Nainital Bank Ltd. & 2018 & 1.000 & 1.000 & 1.000 & 1.000 & 1.000 \\
\hline Jammu \& Kashmir Bank Ltd. & 2018 & 0.557 & 0.949 & 0.881 & 0.587 & 0.632 \\
\hline IDFC First Bank Limited & 2018 & 1.000 & 1.000 & 1.000 & 1.000 & 1.000 \\
\hline Federal Bank Ltd. & 2018 & 1.000 & 1.000 & 1.000 & 1.000 & 1.000 \\
\hline Bandhan Bank Limited & 2018 & 1.000 & 1.000 & 1.000 & 1.000 & 1.000 \\
\hline Central Bank of India & 2019 & 1.000 & 1.000 & 1.000 & 1.000 & 1.000 \\
\hline Canara Bank & 2019 & 0.809 & 1.000 & 1.000 & 0.809 & 0.809 \\
\hline Bank of Maharashtra & 2019 & 0.925 & 0.926 & 0.925 & 0.999 & 1.000 \\
\hline State Bank of India & 2019 & 0.642 & 1.000 & 1.000 & 0.642 & 0.642 \\
\hline Oriental Bank of Commerce & 2019 & 0.859 & 0.906 & 0.894 & 0.948 & 0.961 \\
\hline Punjab National Bank & 2019 & 0.862 & 1.000 & 1.000 & 0.862 & 0.862 \\
\hline Andhra Bank & 2019 & 0.914 & 1.000 & 1.000 & 0.914 & 0.914 \\
\hline Indian Overseas Bank & 2019 & 1.000 & 1.000 & 1.000 & 1.000 & 1.000 \\
\hline Corporation Bank & 2019 & 1.000 & 1.000 & 1.000 & 1.000 & 1.000 \\
\hline Vijaya Bank & 2019 & 0.708 & 1.000 & 1.000 & 0.708 & 0.708 \\
\hline Union Bank of India & 2019 & 1.000 & 1.000 & 1.000 & 1.000 & 1.000 \\
\hline Bank of India & 2019 & 0.700 & 0.854 & 0.811 & 0.820 & 0.864 \\
\hline Indian Bank & 2019 & 0.965 & 1.000 & 1.000 & 0.965 & 0.965 \\
\hline Allahabad Bank & 2019 & 0.876 & 0.896 & 0.894 & 0.978 & 0.981 \\
\hline Punjab and Sind Bank & 2019 & 0.778 & 0.913 & 0.894 & 0.852 & 0.870 \\
\hline Bank of Baroda & 2019 & 0.951 & 0.952 & 0.952 & 0.999 & 0.999 \\
\hline Syndicate Bank & 2019 & 0.589 & 0.780 & 0.747 & 0.755 & 0.788 \\
\hline United Bank of India & 2019 & 1.000 & 1.000 & 1.000 & 1.000 & 1.000 \\
\hline Dena Bank & 2019 & 0.602 & 0.871 & 0.846 & 0.691 & 0.712 \\
\hline UCO Bank & 2019 & 1.000 & 1.000 & 1.000 & 1.000 & 1.000 \\
\hline DCB Bank Limited & 2019 & 0.827 & 1.000 & 1.000 & 0.827 & 0.827 \\
\hline HDFC Bank Ltd. & 2019 & 1.000 & 1.000 & 1.000 & 1.000 & 1.000 \\
\hline IDBI Bank Limited & 2019 & 1.000 & 1.000 & 1.000 & 1.000 & 1.000 \\
\hline Jammu \& Kashmir Bank Ltd. & 2019 & 0.537 & 0.732 & 0.663 & 0.734 & 0.810 \\
\hline South Indian Bank Ltd. & 2019 & 0.829 & 0.862 & 0.839 & 0.962 & 0.988 \\
\hline Nainital Bank Ltd. & 2019 & 1.000 & 1.000 & 1.000 & 1.000 & 1.000 \\
\hline RBL Bank Limited & 2019 & 0.930 & 1.000 & 1.000 & 0.930 & 0.930 \\
\hline Kotak Mahindra Bank Ltd. & 2019 & 0.776 & 0.821 & 0.786 & 0.945 & 0.988 \\
\hline Federal Bank Ltd. & 2019 & 1.000 & 1.000 & 1.000 & 1.000 & 1.000 \\
\hline City Union Bank Limited & 2019 & 1.000 & 1.000 & 1.000 & 1.000 & 1.000 \\
\hline IndusInd Bank Ltd. & 2019 & 1.000 & 1.000 & 1.000 & 1.000 & 1.000 \\
\hline The Dhanalakshmi Bank Ltd. & 2019 & 1.000 & 1.000 & 1.000 & 1.000 & 1.000 \\
\hline
\end{tabular}


Table 14 (continued)

\begin{tabular}{|c|c|c|c|c|c|c|}
\hline Bank name & Year & CRSTE & OVRSTE & IVRSTE & OSE & ISE \\
\hline Lakshmi Vilas Bank Ltd. & 2019 & 0.700 & 0.718 & 0.744 & 0.975 & 0.941 \\
\hline Bandhan Bank Limited & 2019 & 1.000 & 1.000 & 1.000 & 1.000 & 1.000 \\
\hline CSB Bank Limited & 2019 & 1.000 & 1.000 & 1.000 & 1.000 & 1.000 \\
\hline Karnataka Bank Ltd. & 2019 & 0.996 & 1.000 & 1.000 & 0.996 & 0.996 \\
\hline ICICI Bank Limited & 2019 & 0.828 & 0.896 & 0.839 & 0.924 & 0.986 \\
\hline Karur Vysya Bank Ltd. & 2019 & 0.863 & 1.000 & 1.000 & 0.863 & 0.863 \\
\hline Axis Bank Limited & 2019 & 1.000 & 1.000 & 1.000 & 1.000 & 1.000 \\
\hline IDFC First Bank Limited & 2019 & 1.000 & 1.000 & 1.000 & 1.000 & 1.000 \\
\hline Yes Bank Ltd. & 2019 & 1.000 & 1.000 & 1.000 & 1.000 & 1.000 \\
\hline Tamilnad Mercantile Bank Ltd. & 2019 & 1.000 & 1.000 & 1.000 & 1.000 & 1.000 \\
\hline Oriental Bank of Commerce & 2020 & 0.663 & 0.809 & 0.786 & 0.820 & 0.843 \\
\hline Syndicate Bank & 2020 & 0.571 & 0.775 & 0.719 & 0.737 & 0.794 \\
\hline Bank of Baroda & 2020 & 0.875 & 0.963 & 0.955 & 0.908 & 0.916 \\
\hline Canara Bank & 2020 & 0.807 & 1.000 & 1.000 & 0.807 & 0.807 \\
\hline Punjab and Sind Bank & 2020 & 0.752 & 0.863 & 0.832 & 0.872 & 0.904 \\
\hline Allahabad Bank & 2020 & 0.874 & 0.982 & 0.978 & 0.891 & 0.894 \\
\hline UCO Bank & 2020 & 1.000 & 1.000 & 1.000 & 1.000 & 1.000 \\
\hline Indian Bank & 2020 & 0.974 & 1.000 & 1.000 & 0.974 & 0.974 \\
\hline United Bank of India & 2020 & 0.916 & 1.000 & 1.000 & 0.916 & 0.916 \\
\hline Corporation Bank & 2020 & 0.975 & 1.000 & 1.000 & 0.975 & 0.975 \\
\hline Andhra Bank & 2020 & 0.703 & 0.884 & 0.869 & 0.795 & 0.809 \\
\hline Bank of Maharashtra & 2020 & 1.000 & 1.000 & 1.000 & 1.000 & 1.000 \\
\hline Indian Overseas Bank & 2020 & 0.898 & 0.958 & 0.956 & 0.937 & 0.939 \\
\hline Union Bank of India & 2020 & 1.000 & 1.000 & 1.000 & 1.000 & 1.000 \\
\hline Bank of India & 2020 & 0.803 & 0.984 & 0.978 & 0.816 & 0.821 \\
\hline State Bank of India & 2020 & 0.703 & 1.000 & 1.000 & 0.703 & 0.703 \\
\hline Punjab National Bank & 2020 & 0.953 & 1.000 & 1.000 & 0.953 & 0.953 \\
\hline Central Bank of India & 2020 & 1.000 & 1.000 & 1.000 & 1.000 & 1.000 \\
\hline Federal Bank Ltd. & 2020 & 1.000 & 1.000 & 1.000 & 1.000 & 1.000 \\
\hline The Dhanalakshmi Bank Ltd. & 2020 & 1.000 & 1.000 & 1.000 & 1.000 & 1.000 \\
\hline Kotak Mahindra Bank Ltd. & 2020 & 0.800 & 0.809 & 0.805 & 0.988 & 0.993 \\
\hline Tamilnad Mercantile Bank Ltd. & 2020 & 1.000 & 1.000 & 1.000 & 1.000 & 1.000 \\
\hline City Union Bank Limited & 2020 & 1.000 & 1.000 & 1.000 & 1.000 & 1.000 \\
\hline HDFC Bank Ltd. & 2020 & 1.000 & 1.000 & 1.000 & 1.000 & 1.000 \\
\hline CSB Bank Limited & 2020 & 0.986 & 1.000 & 1.000 & 0.986 & 0.986 \\
\hline South Indian Bank Ltd. & 2020 & 0.802 & 0.850 & 0.833 & 0.943 & 0.962 \\
\hline IDBI Bank Limited & 2020 & 0.667 & 0.670 & 0.668 & 0.996 & 1.000 \\
\hline Yes Bank Ltd. & 2020 & 1.000 & 1.000 & 1.000 & 1.000 & 1.000 \\
\hline Nainital Bank Ltd. & 2020 & 1.000 & 1.000 & 1.000 & 1.000 & 1.000 \\
\hline Karnataka Bank Ltd. & 2020 & 0.974 & 0.975 & 0.975 & 1.000 & 1.000 \\
\hline Karur Vysya Bank Ltd. & 2020 & 1.000 & 1.000 & 1.000 & 1.000 & 1.000 \\
\hline Jammu \& Kashmir Bank Ltd. & 2020 & 0.539 & 0.974 & 0.964 & 0.554 & 0.559 \\
\hline Lakshmi Vilas Bank Ltd. & 2020 & 0.753 & 0.809 & 0.845 & 0.931 & 0.891 \\
\hline IndusInd Bank Ltd. & 2020 & 1.000 & 1.000 & 1.000 & 1.000 & 1.000 \\
\hline
\end{tabular}


Table 14 (continued)

\begin{tabular}{lllllll}
\hline Bank name & Year & CRSTE & OVRSTE & IVRSTE & OSE & ISE \\
\hline DCB Bank Limited & 2020 & 0.735 & 0.740 & 0.775 & 0.992 & 0.948 \\
Bandhan Bank Limited & 2020 & 0.801 & 0.971 & 0.980 & 0.825 & 0.817 \\
RBL Bank Limited & 2020 & 0.841 & 0.881 & 0.890 & 0.954 & 0.944 \\
Axis Bank Limited & 2020 & 1.000 & 1.000 & 1.000 & 1.000 & 1.000 \\
ICICI Bank Limited & 2020 & 0.767 & 0.776 & 0.769 & 0.988 & 0.998 \\
IDFC First Bank Limited & 2020 & 0.716 & 0.745 & 0.757 & 0.961 & 0.945
\end{tabular}

Note: Data Source is Statistical Tables Relating to Banks in India, RBI. CRSTE is the CRS technical efficiency, OVRSTE and IVRSTE are the output and input oriented VRS technical efficiency scores respectively. OSE and ISE are respectively the output and input oriented scale efficiencies. The scores are calculated using the MaxDEA software 
Table 15 Average technical efficiency scores of banks in India based on SFA (2014-2020)

\begin{tabular}{|c|c|c|c|}
\hline Banks & Investments & Non-interest income & Advances \\
\hline Allahabad Bank & 0.886 & 0.914 & 0.994 \\
\hline Andhra Bank & 0.897 & 0.911 & 0.994 \\
\hline Axis Bank Limited & 0.923 & 0.927 & 0.991 \\
\hline Bandhan Bank Limited & 0.973 & 0.752 & 0.989 \\
\hline Bank of Baroda & 0.975 & 0.940 & 0.994 \\
\hline Bank of India & 0.949 & 0.931 & 0.994 \\
\hline Bank of Maharashtra & 0.896 & 0.893 & 0.994 \\
\hline Canara Bank & 0.951 & 0.935 & 0.994 \\
\hline Csb Bank Limited & 0.935 & 0.791 & 0.989 \\
\hline Central Bank of India & 0.895 & 0.899 & 0.994 \\
\hline City Union Bank Limited & 0.922 & 0.873 & 0.990 \\
\hline Corporation Bank & 0.895 & 0.907 & 0.994 \\
\hline Dcb Bank Limited & 0.971 & 0.866 & 0.989 \\
\hline Dena Bank & 0.897 & 0.898 & 0.994 \\
\hline The Dhanalakshmi Bank Ltd. & 0.961 & 0.798 & 0.989 \\
\hline Federal Bank Ltd. & 0.883 & 0.874 & 0.990 \\
\hline Hdfc Bank Ltd. & 0.986 & 0.936 & 0.991 \\
\hline Icici Bank Limited & 0.909 & 0.933 & 0.991 \\
\hline Idbi Bank Limited & 0.849 & 0.913 & 0.993 \\
\hline Idfc First Bank Limited & 0.889 & 0.851 & 0.989 \\
\hline Indian Bank & 0.933 & 0.916 & 0.994 \\
\hline Indian Overseas Bank & 0.862 & 0.898 & 0.994 \\
\hline Indusind Bank Ltd. & 0.942 & 0.895 & 0.990 \\
\hline Ing Vysya Bank & 0.957 & 0.871 & 0.989 \\
\hline Jammu \& Kashmir Bank Ltd. & 0.812 & 0.868 & 0.990 \\
\hline Karnataka Bank Ltd. & 0.852 & 0.857 & 0.990 \\
\hline Karur Vysya Bank Ltd. & 0.876 & 0.861 & 0.990 \\
\hline Kotak Mahindra Bank Ltd. & 0.899 & 0.887 & 0.990 \\
\hline Lakshmi Vilas Bank Ltd. & 0.878 & 0.844 & 0.990 \\
\hline Oriental Bank of Commerce & 0.889 & 0.916 & 0.994 \\
\hline Punjab and Sind Bank & 0.912 & 0.898 & 0.994 \\
\hline Punjab National Bank & 0.950 & 0.931 & 0.994 \\
\hline Rbl Bank Limited & 0.950 & 0.833 & 0.989 \\
\hline South Indian Bank Ltd. & 0.863 & 0.862 & 0.990 \\
\hline State Bank of Bikaner And Jaipur & 0.935 & 0.887 & 0.994 \\
\hline State Bank of Hyderabad & 0.918 & 0.900 & 0.994 \\
\hline State Bank of India & 0.997 & 0.971 & 0.994 \\
\hline State Bank of Mysore & 0.935 & 0.900 & 0.994 \\
\hline State Bank of Patiala & 0.907 & 0.887 & 0.994 \\
\hline State Bank of Travancore & 0.945 & 0.894 & 0.994 \\
\hline Syndicate Bank & 0.915 & 0.912 & 0.994 \\
\hline Tamilnad Mercantile Bank Ltd. & 0.943 & 0.855 & 0.990 \\
\hline
\end{tabular}


Table 15 (continued)

\begin{tabular}{llll}
\hline Banks & Investments & Non-interest income & Advances \\
\hline Uco Bank & 0.889 & 0.902 & 0.994 \\
Union Bank of India & 0.922 & 0.923 & 0.994 \\
United Bank of India & 0.888 & 0.904 & 0.994 \\
Vijaya Bank & 0.931 & 0.903 & 0.994 \\
Yes Bank Ltd. & 0.903 & 0.884 & 0.990 \\
\hline
\end{tabular}

Supplementary Information The online version contains supplementary material available at https://doi. org/10.1007/s40953-021-00247-x.

\section{References}

Aghayi, N., and B. Maleki. 2016. Efficiency measurement of DMUs with undesirable outputs under uncertainty based on the directional distance function: Application on bank industry. Energy 112: 376-387.

Ahmad, H.K., H.G. Mujaddad, and M. Nadeem. 2015. An analysis of banks performance in pakistan using two-step double bootstrap dea approach. Pakistan Economic and Social Review, 331-350.

Aigner, D., C.K. Lovell, and P. Schmidt. 1977. Formulation and estimation of stochastic frontier production function models. Journal of Econometrics 6 (1): 21-37.

Ariff, M., and C. Luc. 2008. Cost and profit efficiency of Chinese banks: A non-parametric analysis. China Economic Review 19 (2): 260-273.

Arora, N., N.G. Arora, and K. Kanwar, 2018. Non-performing assets and technical efficiency of Indian banks: a meta-frontier analysis. Benchmarking: An International Journal.

Assaf, A.G., R. Matousek, and E.G. Tsionas. 2013. Turkish bank efficiency: Bayesian estimation with undesirable outputs. Journal of Banking and Finance 37 (2): 506-517.

Banerjee, A., S. Cole, and E. Duflo. 2004. Banking reform in India. India policy forum. Brookings Institute and NCAER.

Barros, C.P., S. Managi, and R. Matousek. 2012. The technical efficiency of the Japanese banks: Nonradial directional performance measurement with undesirable output. Omega 40 (1): 1-8.

Battese, G.E., and T.J. Coelli. 1992. Frontier production functions, technical efficiency and panel data:with application to paddy farmers in India. Journal of Productivity Analysis 3 (1): 153-169.

Battese, G.E., and T.J. Coelli. 1995. A model for technical inefficiency effects in a stochastic frontier production function for panel data. Empirical Economics 20 (2): 325-332.

Baumol, W.J., J.C. Panzar, and R.D. Willig. 1983. Contestable markets: An uprising in the theory of industry structure: Reply. The American Economic Review 73 (3): 491-496.

Bayeh, A., M. Bitar, R. Burlacu, and T.J. Walker. 2018. Competition, securitization, and efficiency in US Banks. Available at SSRN 3256392.

Benston, G.J. 1965. Branch banking and economies of scale. The Journal of Finance 20 (2): 312-331.

Berg, S.A., F.R. Førsund, L. Hjalmarsson, and M. Suominen. 1993. Banking efficiency in the Nordic countries. Journal of Banking and Finance 17 (2-3): 371-388.

Berger, A.N., and D.B. Humphrey. 1997. Efficiency of financial institutions: International survey and directions for future research. European Journal of Operational Research 98 (2): 175-212.

Bhattacharyya, A., C.K. Lovell, and P. Sahay. 1997. The impact of liberalization on the productive efficiency of Indian commercial banks. European Journal of Operational Research 98 (2): $332-345$.

Bogetoft, P. 2012. Performance Benchmarking. Management for Professionals. https://doi.org/10.1007/ 978-1-4614-6043-5. 
Bogetoft, P., and L. Otto. 2010. Benchmarking with dea, sfa, and r, vol. 157. Springer Science \& Business Media.

Bogetoft, P., and L. Otto. 2011. Data envelopment analysis DEA. In Benchmarking with Dea, Sfa, and $R$ (pp. 81-113). New York: Springer.

Cabral, L.M.B. 2000. Introduction to industrial organization. Cambridge

Cecchini, L., S. Venanzi, A. Pierri, and M. Chiorri. 2018. Environmental efficiency analysis and estimation of $\mathrm{CO} 2$ abatement costs in dairy cattle farms in Umbria (Italy): A SBM-DEA model with undesirable output. Journal of Cleaner Production 197: 895-907.

Chang, T.P., J.L. Hu, R.Y. Chou, and L. Sun. 2012. The sources of bank productivity growth in China during 2002-2009: A disaggregation view. Journal of Banking and Finance 36 (7): 1997-2006.

Charles, V., and M. Kumar. 2012. Ranking of Peruvian banks through super efficiency DEA model variables-return-to-scale. Data Envelopment Analysis and its Applications to Management 116-135.

Charnes, A., and W.W. Cooper. 1984. Preface to topics in data envelopment analysis. Annals of Operations Research 2 (1): 59-94.

Chatterjee, G. 1997. Scale economies in banking: Indian experience in deregulated era. RBI Occasional Papers 18 (1): 25-59.

Cherchye, L., B. De Rock, and B. Walheer. 2015. Multi-output efficiency with good and bad outputs. European Journal of Operational Research 240 (3): 872-881.

Chiu, C.-R., Y.-C. Chiu, Y.-C. Chen, and C.-L. Fang. 2016. Exploring the source of metafrontier inefficiency for various bank types in the two-stage network system with undesirable output. PacificBasin Finance Journal 36: 1-13. https://doi.org/10.1016/j.pacfin.2015.11.003.

Chung, Y.H., R. Färe, and S. Grosskopf. 1997. Productivity and undesirable outputs: a directional distance function approach. Journal of Environmental Management 51 (3), 229-240.

Church, J.R., and R. Ware. 2000. Industrial organization: a strategic approach, 367-369. Homewood: Irwin McGraw Hill.

Coelli, T.J., and G.E. Battese. 1996. Identification of factors which influence the technical inefficiency of Indian farmers. Australian Journal of Agricultural Economics 40 (2): 103-128.

Coelli, T.J., D.S.P Rao, C.J. O’Donnel, and G.E. Batesse 2005. An introduction to efficiency and productivity analysis.

Das, A., and S. Ghosh. 2006. Financial deregulation and efficiency: An empirical analysis of Indian banks during the post reform period. Review of Financial Economics 15 (3): 193-221.

Das, A., A. Nag, and S.C. Ray. 2005. Liberalisation, ownership and efficiency in Indian banking: a nonparametric analysis. Economic and Political Weekly, 1190-1197.

De Koeijer, T.J., G.A.A. Wossink, P.C. Struik, and J.A. Renkema. 2002. Measuring agricultural sustainability in terms of efficiency: The case of Dutch sugar beet growers. Journal of Environmental Management 66 (1): 9-17.

Emrouznejad, A., and G.L. Yang. 2018. A survey and analysis of the first 40 years of scholarly literature in DEA: 1978-2016. Socio-Economic Planning Sciences 61: 4-8.

Fall, F., A.M. Akim, and H. Wassongma. 2018. DEA and SFA research on the efficiency of microfinance institutions: A meta-analysis. World Development 107: 176-188.

Färe, R., S. Grosskopf, C.K. Lovell, and C. Pasurka. 1989. Multilateral productivity comparisons when some outputs are undesirable: a nonparametric approach. The Review of Economics and Statistics 71: 90-98.

Färe, R., S. Grosskopf, M. Norris, and Z. Zhang. 1994. Productivity growth, technical progress, and efficiency change in industrialized countries. The American Economic Review, 66-83.

Favero, C.A., and L. Papi. 1995. Technical efficiency and scale efficiency in the Italian banking sector: A non-parametric approach. Applied Economics 27 (4): 385-395.

Fujii, H., S. Managi, and R. Matousek. 2014. Indian bank efficiency and productivity changes with undesirable outputs: A disaggregated approach. Journal of Banking and Finance 38: 41-50.

Fukuyama, H., and W.L. Weber. 2008. Japanese banking inefficiency and shadow pricing. Mathematical and Computer Modelling 48 (11-12): 1854-1867.

Ghosh, C., J. Hilliard, M. Petrova, and B.V. Phani. 2016. Economic consequences of deregulation: Evidence from the removal of voting cap in Indian banks. Journal of Banking and Finance 72: S19-S38.

Goswami, R., F. Hussain, and M. Kumar. 2019. Banking efficiency determinants in India: A two-stage analysis. Margin: the Journal of Applied Economic Research 13 (4): 361-380. 
Goyal, J., M. Singh, R. Singh, and A. Aggarwal. 2019. Efficiency and technology gaps in Indian banking sector: Application of meta-frontier directional distance function DEA approach. The Journal of Finance and Data Science 5 (3): 156-172.

Greene, W. 2005. Reconsidering heterogeneity in panel data estimators of the stochastic frontier model. Journal of Econometrics 126 (2): 269-303.

Guo, D., and J. Wu. 2013. A complete ranking of DMUs with undesirable outputs using restrictions in DEA models. Mathematical and Computer Modelling 58 (5-6): 1102-1109.

Hafsal, K., A. Suvvari, and S.R.S. Durai. 2020. Efficiency of Indian banks with non-performing assets: Evidence from two-stage network DEA. Future Business Journal 6 (1): 1-9.

Hailu, A., and T.S. Veeman. 2001. Non-parametric productivity analysis with undesirable outputs: An application to the Canadian pulp and paper industry. American Journal of Agricultural Economics 83 (3): 605-616.

Halkos, G., and K.N. Petrou. 2019. Treating undesirable outputs in DEA: A critical review. Economic Analysis and Policy 62: 97-104.

Holmstrom, B.R., and J. Tirole. 1989. The theory of the firm. Handbook of Industrial Organization 1: 61-133.

Humphrey, D. 2019. Panel data in banking: Research issues and data peculiarities. In Panel data econometrics, ed. V. Ddd, 609-637. New York: Academic Press.

Jayaraman, A.R., and M.R. Srinivasan. 2014. Analyzing profit efficiency of banks in India with undesirable output-Nerlovian profit indicator approach. IIMB Management Review 26 (4): 222-233.

Kodde, D.A., and F.C. Palm. 1986. Wald criteria for jointly testing equality and inequality restrictions. Econometrica: Journal of the Econometric Society 54: 1243-1248.

Kohers, T., M.H. Huang, and N. Kohers. 2000. Market perception of efficiency in bank holding company mergers: The roles of the DEA and SFA models in capturing merger potential. Review of Financial Economics 9 (2): 101-120.

Kumar, L., D. Malathy, and L.S. Ganesh. 2010. Productivity growth and efficiency change in Indian banking: Technology effect vs catch-up effect. Journal of Advances in Management Research.

Kumar, M., V. Charles, and C.S. Mishra. 2016. Evaluating the performance of Indian banking sector using DEA during post-reform and global financial crisis. Journal of Business Economics and Management 17 (1): 156-172.

Kumar, S., and R. Gulati. 2010. Measuring efficiency, effectiveness and performance of Indian public sector banks. International Journal of Productivity and Performance Management.

Kumbhakar, S.C., and C.K. Lovell. 2003. Stochastic frontier analysis. Cambridge University Press.

Kumbhakar, S.C., and S. Sarkar. 2003. Deregulation, ownership and efficiency in Indian banking. Arthaniti-Journal of Economic Theory and Practice 2 (1-2): 1-26.

Kumbhakar, S.C. 1990. Production frontiers, panel data, and time-varying technical inefficiency. Journal of Econometrics 46 (1-2), 201-211.

Kumbhakar, S.C., H. Wang, and A.P. Horncastle. 2015. A practitioner's guide to stochastic frontier analysis using Stata. Cambridge University Press.

Lansink, A.O., and I. Bezlepkin. 2003. The effect of heating technologies on $\mathrm{CO}_{2}$ and energy efficiency of Dutch greenhouse firms. Journal of Environmental Management 68 (1): 73-82.

Levine, R., and S. Zervos. 1998a. Stock markets, banks, and economic growth. American Economic Review 537-558.

Levine, R., and S. Zervos. 1998b. Capital control liberalization and stock market development. World Development 26 (7): 1169-1183.

Luo, X. 2003. Evaluating the profitability and marketability efficiency of large banks: An application of data envelopment analysis. Journal of Business Research 56 (8): 627-635.

McKinsey \& Company. 2019. The last pit stop? Time for late bold-cycle moves. McKinsey global banking annual review 2019. McKinsey \& Company.

Meeusen, W., and J. van Den Broeck. 1977. Efficiency estimation from Cobb-Douglas production functions with composed error. International Economic Review 18: 435-444.

Mester, L.J. 1996. A study of bank efficiency taking into account risk-preferences. Journal of Banking and Finance 20 (6): 1025-1045.

Miller, S.M., and A.G. Noulas. 1996. The technical efficiency of large bank production. Journal of Banking and Finance 20 (3): 495-509. 
Mohan, T.R., and S.C. Ray. 2004. Comparing performance of public and private sector banks: A revenue maximisation efficiency approach. Economic and Political Weekly 1271-1276.

Mukta, M. 2016. Efficiency of commercial banks in India: A DEA approach. Pertanika Journal of Social Sciences and Humanities 24 (1): 151-170.

Odeck, J., and H. Schøyen. 2020. Productivity and convergence in Norwegian container seaports: An SFA-based Malmquist productivity index approach. Transportation Research Part a: Policy and Practice 137: 222-239.

Park, K.H., and W.L. Weber. 2006. A note on efficiency and productivity growth in the Korean banking industry, 1992-2002. Journal of Banking and Finance 30 (8): 2371-2386.

Pathomsiri, S., A. Haghani, M. Dresner, and R.J. Windle. 2008. Impact of undesirable outputs on the productivity of US airports. Transportation Research Part E: Logistics and Transportation Review 44 (2): 235-259.

Petrou, A. 2014. Economic efficiency. Encyclopedia of Quality of Life and Well-Being Research. https:// doi.org/10.1007/978-94-007-0753-5_818.

Puri, J., and S.P. Yadav. 2014. A fuzzy DEA model with undesirable fuzzy outputs and its application to the banking sector in India. Expert Systems with Applications 41 (14): 6419-6432.

Rajaraman, I., and G. Vasishtha. (2002). Non-performing loans of PSU banks: Some panel results. Economic and Political Weekly, 429-435.

Rangrajan, C., and P. Mempilly. 1972. Economies of scale in Indian banking in technical studies for banking commission report. Reserve Bank of India, Mumbai 244-268.

Ray, S.C., and A. Das. 2010. Distribution of cost and profit efficiency: Evidence from Indian banking. European Journal of Operational Research 201 (1): 297-307.

Resti, A. 1997. Evaluating the cost-efficiency of the Italian banking system: What can be learned from the joint application of parametric and non-parametric techniques. Journal of Banking and Finance 21 (2): 221-250.

Reinhard, S., C.K. Lovell, and G.J. Thijssen. 2000. Environmental efficiency with multiple environmentally detrimental variables; estimated with SFA and DEA. European Journal of Operational Research 121 (2): 287-303.

Safiullah, M., and A. Shamsuddin. 2020. Technical efficiency of Islamic and conventional banks with undesirable output: Evidence from a stochastic meta-frontier directional distance function. Global Finance Journal 100547.

Saha, A., and T.S. Ravisankar. 2000. Rating of Indian commercial banks: A DEA approach. European Journal of Operational Research 124 (1): 187-203.

Sahoo, B.K., J. Sengupta, and A. Mandal. 2007. Productive performance evaluation of the banking sector in India using data envelopment analysis. International Journal of Operations Research, Forthcoming.

Sathye, M. 2003. Efficiency of banks in a developing economy: The case of India. European Journal of Operational Research 148 (3): 662-671.

Sealey, C.W., Jr., and J.T. Lindley. 1977. Inputs, outputs, and a theory of production and cost at depository financial institutions. The Journal of Finance 32 (4): 1251-1266.

Scheel, H. 2001. Undesirable outputs in efficiency valuations. European Journal of Operational Research 132 (2): 400-410.

Schmalensee, R. 1989. Inter-industry studies of structure and performance. Handbook of Industrial Organization 2: 951-1009.

Sengupta, A., and S. De. 2020. Measuring efficiency of Indian Banks using window DEA analysis. India Studies in Business and Economics, 101-111.

Sharma, A.K., D. Sharma, and M.K. Barua. 2012. Efficiency and productivity of indian banks: an application of data envelopment analysis and tobit regression. In National Conference on Emerging challenges for sustainable Business (pp. 81-90).

Shirazi, F., and E. Mohammadi. 2019. Evaluating efficiency of airlines: A new robust DEA approach with undesirable output. Research in Transportation Business and Management 33: 100467.

Silva, T.C., B.M. Tabak, D.O. Cajueiro, and M.V.B. Dias. 2017. A comparison of DEA and SFA using micro-and macro-level perspectives: Efficiency of Chinese local banks. Physica A: Statistical Mechanics and Its Applications 469: 216-223.

Stewart, C., R. Matousek, and T.N. Nguyen. 2016. Efficiency in the Vietnamese banking system: A DEA double bootstrap approach. Research in International Business and Finance 36: 96-111. 
Strange, N., P. Bogetoft, G.O. Aalmo, B. Talbot, A.H. Holt, and R. Astrup. 2021. Applications of DEA and SFA in benchmarking studies in forestry: State-of-the-art and future directions. International Journal of Forest Engineering, 1-10.

Subrahmanyam, G. 1993. Productivity growth in India's public sector banks: 1979-89. Journal of Quantitative Economics 9 (3): 209-223.

Thoraneenitiyan, N., and N.K. Avkiran. 2009. Measuring the impact of restructuring and country-specific factors on the efficiency of post-crisis East Asian banking systems: Integrating DEA with SFA. Socio-Economic Planning Sciences 43 (4): 240-252.

Thyagarajan, M. 1975. Expansion of commercial banking: An assessment. Economic and Political Weekly 1819-1824.

Tone, K. 2001. A slacks-based measure of efficiency in data envelopment analysis. European Journal of Operational Research 130 (3): 498-509.

Tone, K. 2004. Malmquist productivity index. In Handbook on data envelopment analysis, 203-227. Boston: Springer.

Tone, K. 2011. Slacks-based measure of efficiency. In Handbook on data envelopment analysis, 195-209. Boston: Springer.

Tsolas, I.E., and V. Charles. 2015. Incorporating risk into bank efficiency: A satisficing DEA approach to assess the Greek banking crisis. Expert Systems with Applications 42 (7): 3491-3500.

Tzeremes, N.G. 2015. Efficiency dynamics in Indian banking: A conditional directional distance approach. European Journal of Operational Research 240 (3): 807-818.

Wang, K., W. Huang, J. Wu, and Y.N. Liu. 2014. Efficiency measures of the Chinese commercial banking system using an additive two-stage DEA. Omega 44: 5-20.

Wanke, P., M.G. Tsionas, Z. Chen, and J.J.M. Antunes. 2020. Dynamic network DEA and SFA models for accounting and financial indicators with an analysis of super-efficiency in stochastic frontiers: An efficiency comparison in OECD banking. International Review of Economics and Finance 69: 456-468.

Wheelock, D.C., and P. Wilson. 1995. Evaluating the efficiency of commercial banks: does our view of what banks do matter? Review 77.

Yang, H., and M.G. Pollitt. 2007. Distinguishing weak and strong disposability among undesirable outputs in DEA: The example of the environmental efficiency of Chinese coal-fired power plants. Electricity Policy Research Group, University of Cambridge.

Yang, H., and M. Pollitt. 2009. Incorporating both undesirable outputs and uncontrollable variables into DEA: The performance of Chinese coal-fired power plants. European Journal of Operational Research 197 (3): 1095-1105.

Yue, P. (1992). Data envelopment analysis and commercial bank performance: a primer with applications to Missouri banks. IC Institute Articles.

Zha, Y., N. Liang, M. Wu, and Y. Bian. 2016. Efficiency evaluation of banks in China: A dynamic twostage slacks-based measure approach. Omega 60: 60-72.

Zhao, L., Q. Zhu, and L. Zhang. 2021. Regulation adaptive strategy and bank efficiency: A network slacks-based measure with shared resources. European Journal of Operational Research.

Zhou, X., Z. Xu, J. Chai, L. Yao, S. Wang, and B. Lev. 2019. Efficiency evaluation for banking systems under uncertainty: A multi-period three-stage DEA model. Omega 85: 68-82.

Publisher's Note Springer Nature remains neutral with regard to jurisdictional claims in published maps and institutional affiliations. 


\section{Authors and Affiliations}

\section{Ather Hassan Dar ${ }^{1} \cdot$ Somesh Kumar Mathur ${ }^{1} \cdot$ Sila Mishra ${ }^{1}$}

$\triangle$ Somesh Kumar Mathur

skmathur@iitk.ac.in

Ather Hassan Dar

atherdar@iitk.ac.in

Sila Mishra

silamish@iitk.ac.in

1 Department of Economic Sciences IIT Kanpur, Kanpur, India 